\title{
Zoonotic Hepatitis E Virus: Classification, Animal Reservoirs and Transmission Routes
}

\author{
Virginie Doceul ${ }^{1,2,3}$, Eugénie Bagdassarian ${ }^{1,2,3}$, Antonin Demange ${ }^{1,2,3}$ and Nicole Pavio ${ }^{1,2,3, *}$ \\ 1 French Agency for Food, Environmental and Occupational Health \& Safety (ANSES), \\ Animal Health Laboratory, UMR (joint research unit) 1161 Virology, 94701 Maisons-Alfort, France; \\ virginie.doceul@vet-alfort.fr (V.D.); eugenie.bagdassarian@vet-alfort.fr (E.B.); \\ antonin.demange@vet-alfort.fr (A.D.) \\ 2 French National Institute for Agricultural Research (INRA), UMR (joint research unit) 1161 Virology, \\ 94700 Maisons-Alfort, France \\ 3 Association of Universities and High Education Institutions (ComUE), Paris-Est Créteil \\ Val-de-Marne University, National Veterinary School, UMR (joint research unit) 1161 Virology, \\ 94700 Maisons-Alfort, France \\ * Correspondence: nicole.pavio@anses.fr; Tel.: +33-1-439-67209 \\ Academic Editor: Jacques Izopet \\ Received: 22 July 2016; Accepted: 22 September 2016; Published: 3 October 2016
}

\begin{abstract}
During the past ten years, several new hepatitis E viruses (HEVs) have been identified in various animal species. In parallel, the number of reports of autochthonous hepatitis $E$ in Western countries has increased as well, raising the question of what role these possible animal reservoirs play in human infections. The aim of this review is to present the recent discoveries of animal HEVs and their classification within the Hepeviridae family, their zoonotic and species barrier crossing potential, and possible use as models to study hepatitis E pathogenesis. Lastly, this review describes the transmission pathways identified from animal sources.
\end{abstract}

Keywords: hepatitis E virus (HEV); animals; zoonotic reservoir; foodborne transmission

\section{Introduction}

Hepatitis E virus (HEV) is a single stranded, positive RNA virus belonging to the Hepeviridae family. Its genome codes for three open reading frames (ORFs) and is $7.2 \mathrm{~kb}$ in length. HEV is the leading cause of enterically transmitted hepatitis worldwide. HEV infection can cause an acute hepatitis that is self-limited. However, fulminant hepatic failure can occur in patients with underlying chronic liver disease, in the elderly, and in pregnant women. Complications and extra-hepatic manifestations of hepatitis E, such as acute pancreatitis, renal failure and neurological syndromes including Guillain-Barré syndrome, neuralgic amyotrophy or encephalitis, can also occur [1]. In addition, patients with underlying liver disease and/or immune-deficiencies can develop chronic hepatitis E, exacerbation of liver diseases and cirrhosis, leading to liver transplantation [2,3].

The existence of HEV was postulated for the first time during an outbreak of hepatitis in Kashmir Valley in 1978 [4]. HEV, named at that time "enterically transmitted non-A and non-B hepatitis", was subsequently identified after a human volunteer was infected experimentally with a pooled faecal extract from affected military personnel [5]. This volunteer later developed acute hepatitis and spherical 27- to 30-nm virus-like particles (VLPs) were visualised in his stool by immune electron microscopy (IEM). In the early 1990s, the HEV genome was cloned and sequenced using samples obtained from experimentally infected macaques $[6,7]$.

Since the end of the 1990s, additional HEV-related agents have been identified in a large variety of animals ranging from domestic swine, wild boar, deer, rabbit, mongoose, ferret, rat and chicken to bat and cutthroat trout. Following the identification of these novel strains, a new classification has been 
proposed that divides the Hepeviridae family into two genera: Orthohepevirus and Piscihepevirus [8]. Most of the HEV strains identified so far belong to the Orthohepevirus genus that is divided into four species: Orthohepevirus $A, B, C$ and $D$ (Figure 1). Four main genotypes of HEV that belong to the Orthohepevirus $A$ species are able to infect humans (HEV-1 to -4). Genotypes 1 and 2 (HEV-1 and HEV-2) infect only humans and are associated with large waterborne epidemics in tropical and subtropical areas. Genotypes 3 and 4 (HEV-3 and HEV-4) are present in humans and other animals, and are the main cause of autochthonous cases of hepatitis $E$ in industrialized countries.

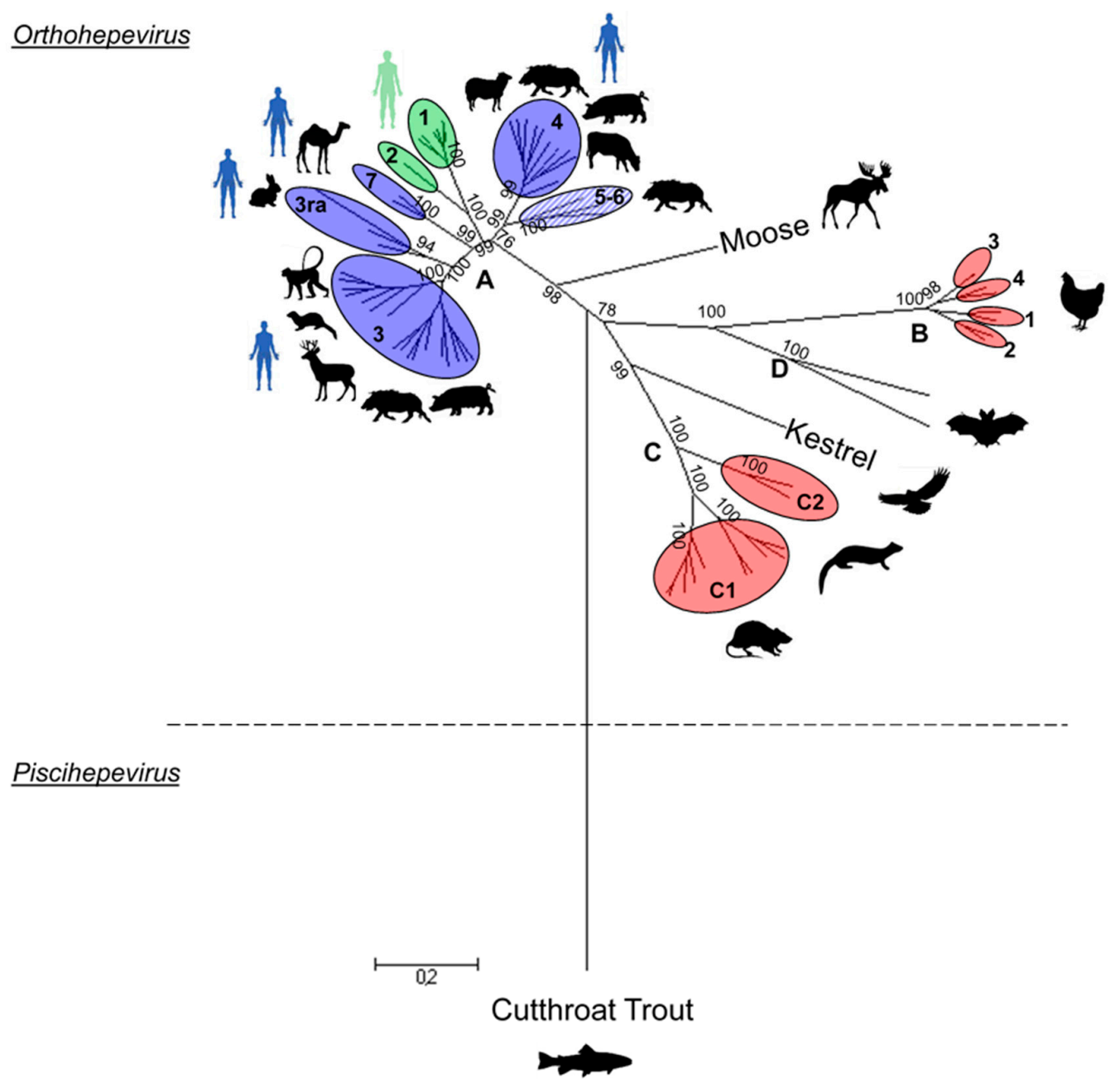

Figure 1. Phylogenetic tree of representative members of the Hepeviridae family. The tree was inferred using the Maximum Likelihood method based on the Tamura-Nei model. The analysis was performed with 67 hepatitis E virus (HEV) complete genomes or complete coding sequences available in the GenBank database and representative of each genotype. The sequence size varies between 6543 and $7318 \mathrm{nt}$ in length, and they were aligned using Clustal W. The bootstraps were obtained from 1000 replicates and values over $70 \%$ are indicated at the genotype level. The initial tree was obtained by applying the Neighbour-Joining method to a matrix of pairwise distances estimated using the Maximum Composite Likelihood (MCL) approach. The tree is drawn to scale, with branch lengths proportional to the number of substitutions per site. Evolutionary analyses were conducted using Molecular Evolutionary Genetics Analysis (Version 6.0). The Orthohepevirus species taxon name is added at the junction of the last common ancestor for each species. Genotypes of non-zoonotic HEV species (red), genotypes including HEV strains isolated from animals and human (blue), genotypes infecting human only (green) and genotypes infecting wild boar that are not linked to human infections (striped blue) are shown. 
The first HEV-related agent identified in an animal was swine HEV. HEV RNA and HEV-specific antibodies were first detected in domestic swine in Nepal in 1995 [9]. Two years later, a swine strain of HEV was identified in pig herds from the United States (US) and characterised genetically [10]. Pigs inoculated intravenously with swine HEV developed viremia prior to seroconversion, had histological evidence of hepatitis, but did not display clinical symptoms [11]. Swine is the major reservoir of zoonotic HEV-3 and HEV-4 worldwide and is highly prevalent in pig herds. Indeed, anti-HEV antibodies were detected in $46 \%-100 \%$ of swine farms from many countries [12-14]. HEV-3 and HEV-4 are also able to infect wild boars, which represent, along with domestic pigs, a major reservoir of zoonotic HEV [12,13]. HEV-3 strains have also been detected in different species of deer and in the Japanese mongoose [15-17]. In addition, rabbit HEV-3 strains have been identified in farmed rabbits in China [18] and the US [19], in farmed and wild rabbits in France [20] and also in a pet house rabbit [21]. In the Orthohepevirus $A$ species, two other strains of $\mathrm{HEV}$, classified as genotype 5 and 6 (HEV-5 and HEV-6), have also been identified in wild boar in Japan $[8,22]$ and more recently, HEV-7 has been detected in faecal samples from camels [23]. An HEV strain has been characterised in Swedish moose [24] but it is still not assigned to any HEV species.

Additional animal species infected with HEV have also been described. However, the HEV strains detected in these animals are genetically more distant from human HEV strains and are classified as different Orthohepevirus species. Avian HEV (Orthohepevirus B) was first described in the United States, and is associated with hepatitis-splenomegaly (HS) syndrome in chickens [25], also called big liver and spleen disease [26]. Avian HEV is enzootic in chicken flocks in the US with a seroprevalence of $71 \%$ [27]. A rat strain of HEV has been identified in rats [28], with a seroprevalence rate varying from $13 \%$ to $90 \%$ in many countries [13]. Other HEV variants have been identified in ferrets in the Netherlands [29] and in mink in Denmark [30] (Orthohepevirus C). Partial sequences with the highest homology to rat HEV have also been detected in foxes [31]. Another species of HEV was identified in different bats from Central America, Africa and Europe (Orthohepevirus D) [32]. Very recently, a HEV strain that might represent a novel Orthohepevirus species has been found and characterized in kestrels and falcons in Europe [33]. Finally, a more distant strain of HEV has been discovered in the cutthroat trout in the US and assigned to the Piscihepevirus genus [34].

Anti-HEV antibodies have also been detected in different animal species including goats, sheep, buffalo, work horses, cats and dogs. This suggests that these animal species have been exposed to HEV or a closely related agent. However, no HEV RNA has been identified formally in these animals yet. The design of molecular tools used to detect HEV RNA is based on known HEV sequences and might not be able to detect distantly related variants. It is then likely that other animal strains of HEV exist.

In the past 20 years, new molecular tools and the use of metagenomics have highlighted the diversity of HEV strains and susceptible hosts existing. These discoveries have greatly contributed to a better phylogenetic analysis and classification of the Hepeviridae family. In parallel, animal models of HEV infection have been developed and used to study cross-species transmission of the virus and routes of transmission of zoonotic HEV have been identified. This article reviews these recent advances that have contributed to a better understanding of the origins and transmission of zoonotic hepatitis $\mathrm{E}$.

\section{HEV Phylogeny}

To date, 240 complete genomes are available in Genbank (NCBI database), compared to 49 complete genomes available in 2006, with more than 120 sequences of HEV-3. The use of full-length sequences has improved the phylogeny and classification of HEV, but trees generated previously, using shorter sequences from selected genomic regions (partial-ORF1 or partial-ORF2), show similar structures than those generated with full genomes [35].

Within genotypes, a high diversity can be observed requiring further classification into subtypes or clade/group and subclade/subgroup (genotype 3, Figure 2) [35-37]. Thus, a methodology was recently proposed to standardise HEV subtyping. Using this method, subtypes can be redefined when novel full-sequences are added (Figure 2) [38]. 


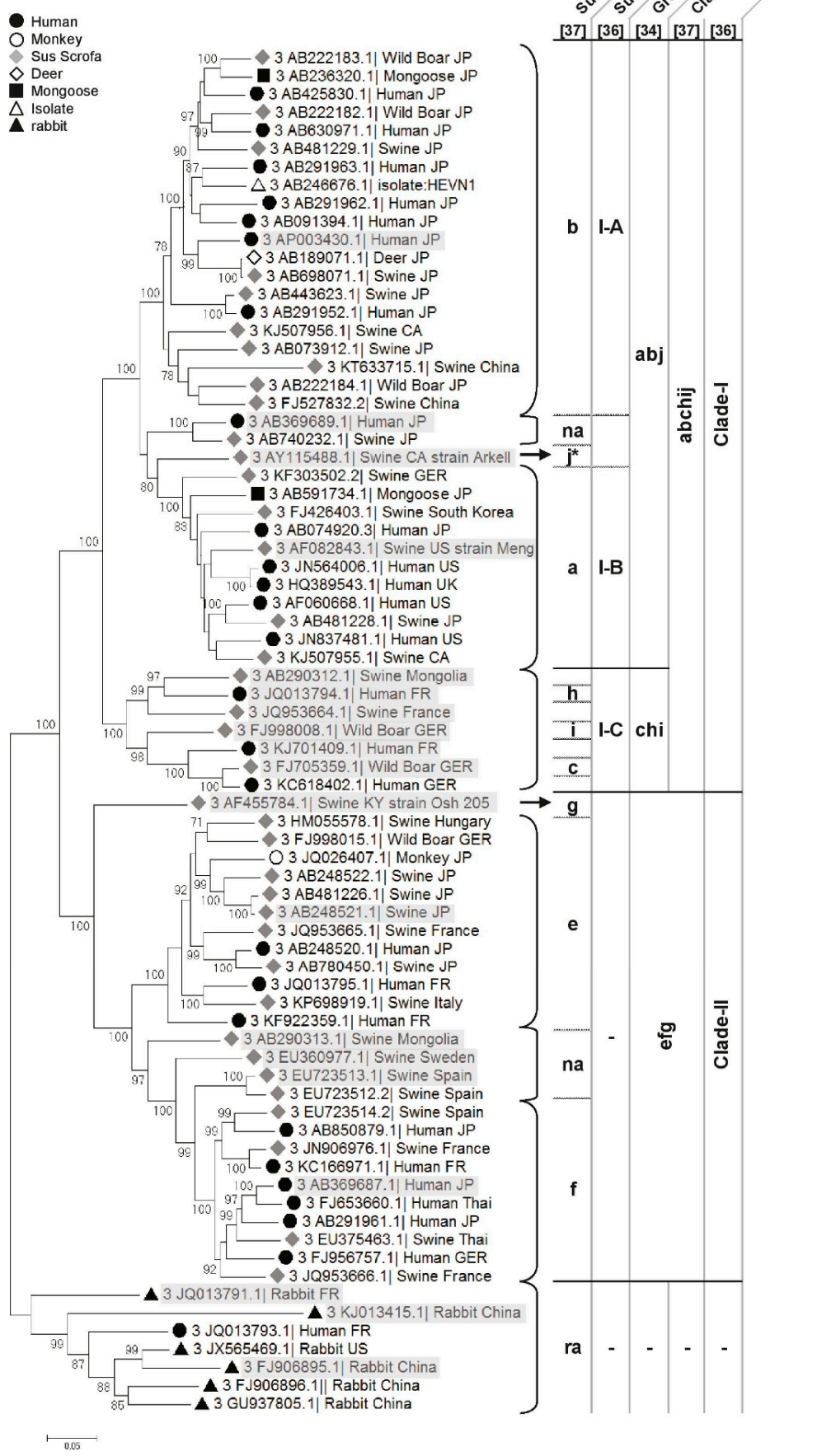

Figure 2. Phylogenetic tree of HEV-3. The tree was inferred using the Maximum Likelihood method based on the Tamura-Nei model. The analysis involved the 75 most representative HEV-3 complete sequences/cds available on the GenBank database and aligned using the clustal W method. The bootstraps were obtained from 1000 replicates and values $>70 \%$ are indicated. The initial tree was obtained by applying the Neighbour-Joining method to a matrix of pairwise distances estimated using the MCL approach. The tree is drawn to scale, with branch lengths proportional to the number of substitutions per site. Evolutionary analyses were conducted using Molecular Evolutionary Genetics Analysis (Version 6.0). Cluster names from the classification proposed by Lu et al., Vina-Rodrigues et al. and Smith et al. (letters a to $\mathrm{j}$ and ra cluster) are indicated in the table on the right side of the tree [35,38,39] and by Mirazo et al. (Clade-I and -II and subclades I-A to I-C) [37]. Reference sequences of the different HEV subtypes used by Smith et al. [38] are highlighted in grey. The symbols to the left of the different HEV strains indicate the host of origin. na = non assigned. 


\subsection{Piscihepevirus Genus}

The Piscihepevirus genus (Figure 1) is composed of one species, Piscihepevirus $A$, and one member, the cutthroat trout virus (CTV) [34] that infects the salmonid fish. CTV is the genetically most distant virus within the Hepeviridae family. It shares $41 \%$ to $46 \%$ nucleotides (nt) identity and $13 \%$ to $26 \%$ amino acid (aa) identity with the Orthohepevirus genus [8,34].

\subsection{Orthohepevirus Genus}

\subsubsection{Orthohepevirus $A$}

The Orthohepevirus $A$ is the best-characterized species sharing $52.44 \%$ to $59.11 \%$ nt identity with the other Orthohepevirus species, excluding the moose strain (64.5\%).

Genotypes 1 and 2

These two human genotypes are genetically close with almost $76 \%$ nt identity. HEV-1 is well described and divided into six subtypes (1a to 1f) while HEV-2 is less documented and divided into 2 subtypes (2a and 2b) (Figure 1) [38]. Strains belonging to genotype 1 share $88.53 \%$ to $94.05 \%$ nt identity and are found mainly in Asia, Africa and Mexico [40]. Genotype 2 strains were isolated in Central America (Mexico) and Africa (Tchad, Nigeria) [39,41-43].

\section{Genotype 3}

HEV-3 is the best described and documented genotype in Genbank. Most sequences originate from humans, pigs and wild boars (Figure 2). HEV-3 is divided into 10 subtypes (a to $\mathrm{j}$ ) and two clades (3abchij and 3efg) [35,36,38,44,45] (Figure 2), sharing $78.74 \%$ to $82.46 \%$ nt identity. HEV-3 includes some unassigned strains [38] and rabbit HEV for which genotyping it is still under consideration.

Evolutionary studies suggest that the most recent common ancestor for genotype 3 appeared in early 19th century [46] or even in the late 18th century, considering HEV-like outbreak descriptions [47]. Phylogenetic trees are constructed with recent HEV strains using Bayesian approaches to estimate HEV evolution [46]; there are potentially recent bottlenecks through which the various genotypes have passed. A wider sampling of HEV genotypes may show that the present estimates are underestimates of the true evolutionary history of HEV.

1. Clade 3abchij: Within this first clade, HEV strains can be separated into two subclades, 3abj and $3 \mathrm{chi}$, sharing $81.16 \%$ to $85.33 \%$ nt identity (Figure 2) [35]. HEV strains that cluster in the $3 \mathrm{chi}$ subclade share $84.7 \%$ to $96.46 \%$ nt identity and originate from Europe (France and Germany) and Mongolia. HEV strains within the 3abj subclade share more than $83.75 \%$ nt identity. They were isolated in Asia, Europe and North America and are predominantly circulating in Asia and North America. Complete genomes of subtype 3a are from North America and evolutionary studies suggest that it came from Asia and diverged from subtype $3 b$ to subtype $3 a$ in the early 1920 s $[37,40]$. In the subtype $3 \mathrm{~b}$, nearly $90 \%$ of the full genomes are from Japan, sharing more than $95 \%$ nt identity [35,37] (Figure 2). Studies on the origin of HEV in Japan suggest that HEV-3 was imported from Europe in the early 20th century and then diverged into the $3 b$ subtype $[37,40]$. The subtype $3 \mathbf{j}$ was isolated from a pool of pig faecal samples in North America [48], thus, full genome sequences from single animals must be added to validate this subtype [35].

2. Clade 3efg: This clade includes the three subtypes e, $f$ and g, sharing $82.75 \%-90.57 \%$ nt identity, and 3 non-assigned subtypes. Subtypes $3 e$ and $3 f$ are mainly found in Asia and Europe $[49,50]$. Evolutionary studies have hypothesised that these HEV strains have emerged in Europe around 1871 [37]. There is only one complete sequence for the subtype $3 \mathrm{~g}$ from Kirgizstan, which is the most divergent virus of this clade (Figure 2). The classification of the subtype $3 \mathrm{~d}$ is based on one partial ORF2 sequence from Taiwan, it shares $86.18 \%$ and $84.87 \%$ nt identity with the subtypes $3 \mathrm{~g}$ and $3 \mathrm{~h}$, respectively. Subtype $3 \mathrm{~d}$ does not belong to any clade so far. 
3. Subtype 3 ra (rabbit): These strains share $73 \%$ to $80 \%$ nt identity with other HEV-3 subtypes and form a distinct clade within genotype 3 (Figure 2). This divergence is mainly due to numerous substitutions and insertions in the rabbit HEV genome compared to the other Orthohepevirus A HEV strains [8,51]. As rabbit strains better cluster with other genotype 3 strains, they are provisionally assigned as subtype 3ra [8,38] and divided into 2 subclades [38]. This subtype includes a strain isolated from a human case of hepatitis $\mathrm{E}$ in France that shares $80.12 \%$ to $86.14 \%$ nt identity with the other rabbit strains [51].

\section{Genotype 4}

HEV-4 is mainly found in Asian countries and share between $71.79 \%$ and $77.38 \%$ nt identity with other genotypes (Figure 1). It is divided into nine subtypes (a-i) mainly isolated from pig, wild boar and human. HEV-4 was also detected in other animals such as sheep, cow and goat in China [52,53]. Nevertheless, more investigations are necessary to determine if these species are reservoirs of HEV-4 or accidental hosts.

Genotypes 5 and 6

Genotypes 5 and 6 were amplified from wild boars only. They are assigned as subtypes $5 \mathrm{a}$ and $6 \mathrm{a}$ (Figure 1), sharing more than $78 \%$ nt identity amongst themselves and $71.58 \%-77.38 \%$ nt identity with other genotypes. Up to now, there is no human infection associated with these genotypes.

\section{Genotype 7}

Three complete or partial sequences assigned to genotype 7 have been described. Two of them were isolated from camel (Figure 1) [23]. The third one originates from a human transplant patient and is lacking most of the ORF3 region [54]. These strains are close to each other ( $>86 \%$ nt identity) and share $72.55 \%-76.13 \%$ nt identity with other genotypes.

\subsubsection{Orthohepevirus $B$}

Orthohepevirus B strains were amplified from chicken and represent the shortest HEV genome $(6.65 \mathrm{~kb})$. This HEV species shares $51.47 \%-55.05 \%$ nt identity with other Orthohepevirus species. To date, there are four different genotypes described from different countries worldwide [55-57] (Figure 1) and sharing a low divergence $(<6 \%)[8]$.

\subsubsection{Orthohepevirus C}

The Orthohepevirus C species shares $51.68 \%-60.57 \%$ nt identity with other Orthohepevirus species. Two different genotypes can be distinguished: $\mathrm{C} 1$ and $\mathrm{C} 2$. Genotype $\mathrm{C} 1$ includes strains isolated from rat (Figure 1). However, some variants with incomplete sequences, isolated from bandicoot and Asian musk shrew, cluster also in this genotype [58,59]. The phylogeny analysis of the full genomes available shows three different clusters within this genotype that may constitute three possible subtypes (Figure 1).

Genotype C2 is composed of HEV variants isolated from ferret and mink [8,30] (Figure 1). Only two full sequences of ferret are available sharing $81.9 \%$ nt identity.

\subsubsection{Orthohepevirus $D$}

The Orthohepevirus D species includes only bat HEV. To date, three full genomes are available and constitute the shortest mammalian HEV genome $(6.8 \mathrm{~kb})$ [32]. This HEV species shares between $52.8 \%$ and $56.06 \%$ nt identity with other Orthohepevirus species (Figure 1). A phylogeny analysis with partial sequences isolated from many different countries has shown a high diversity within the Orthohepevirus $D$ species, suggesting that several genotypes can be distinguished [32]. 


\subsubsection{Unassigned Orthohepeviruses}

\section{Swedish Moose}

HEV strains were recently isolated from Swedish moose [60] (Figure 1). Only one partial genome with complete ORFs is available. A phylogenetic analysis with partial sequences has shown high similarities between different moose strains from the same geographic region ( $>91 \%$ nt identity) [24]. They form a distinct group within the Orthohepevirus genus and are close to the Orthohepevirus A species (63\% nt identity).

\section{Kestrel (Falconidae)}

Very recently, a full HEV genome was retrieved from Kestrel [33]. This HEV strain is similar to the other HEV strains in terms of genome length and organization with $51.47 \%-60.57 \%$ nt identity with others Orthohepevirus species (Figure 1). This cluster could constitute a new Orthohepevirus species, close to the Orthohepevirus C species (58.65\%-60.57\% nt identity). Partial sequences show a low diversity ( $>87 \%$ nt and $99 \%$ aa identities) but broader investigations are necessary to better characterize it.

Zoonotic strains of the Orthohepevirus A species are more frequently studied and better classified than non-zoonotic HEV. Additional HEV complete sequences from ferret, bat, moose or Cutthroat trout, from various origins (geographic, related host), would improve the classification $[24,36,61]$.

\section{Animal models of HEV}

\subsection{Non-Human Primates (Historical Model)}

A number of non-human primate species has shown susceptibility to HEV infection, including chimpanzee, rhesus monkeys, African green monkeys, owl monkey, Tamarin and squirrel monkeys [62]. Natural infection and transmission of HEV-3 has been described in a monkey facility in Japan [63]. In addition, cynomolgus and rhesus macaques can be infected experimentally with HEV-1 to HEV-4 [64-67] and have served as the primary model of HEV infection [62,68]. Experimental infection of a cynomolgus macaque with a suspension of stool from human patients led to the excretion of VLPs $[5,69,70]$ and the development of hepatitis, characterised by liver enzyme elevations, viremia and seroconversion [69-73]. Moreover, the course of infection in experimentally-infected primates is similar to the one in humans with variable incubation periods. An important application of non-human primate studies was to evaluate the efficacy of potential HEV vaccines [74,75]. Non-human primates were also used to evaluate the zoonotic potential of different HEV strains. It was shown that rhesus monkeys and a chimpanzee, experimentally inoculated with swine HEV-3, developed hepatitis [76]. Inoculation of rhesus monkeys with swine HEV-4 also led to seroconversion and viremia but no significant increase in the serum level of alanine aminotransferase (ALT) was observed [77]. The infection of two cynomolgus macaques with rabbit HEV led to the development of a typical hepatitis, suggesting that rabbits may be a source of human HEV infection [78]. However, attempts of cross-species transmission of avian, rat or ferret HEV to non-human primates under experimental condition were unsuccessful [55,79]. Due to limited resources, ethical concerns, and difficult and expensive experimental procedures, little has been learned about the pathogenesis of HEV using primate models.

The discovery of HEV strains in different animal species has then led to the development of other naturally occurring animal models.

\subsection{Swine}

Swine HEV was identified in 1997 and was shown to be antigenically and genetically related to human HEV [10]. Swine is a natural host of HEV-3 and -4 and specific pathogen free (SPF) pigs have been successfully infected intravenously with samples recovered from patients suffering from hepatitis 
E infection (HEV-3 and -4) [11,76,80,81]. Infected pigs presented mild gross and microscopic liver lesions, viremia, seroconverted and excreted viable HEV in the faeces. Evidences of extrahepatic sites of HEV replication have also been demonstrated in pigs inoculated intravenously [82,83]. Cross-species transmission experiments were performed using the swine model. SPF pigs were successfully infected with two different rabbit strains of HEV, but not with rat HEV [84]. More recently, transmission of HEV from infected wild boar to wild boar and domestic pigs by contact between the animals was demonstrated [85,86]. However, pigs are resistant to experimental infection with HEV-1 and -2 [81] and swine HEV causes only subclinical infection. There is no evidence of clinical disease or elevation of the liver enzyme ALT in this model, thus limiting its usefulness in pathogenicity studies. Nevertheless, this naturally occurring swine model remains very useful for the study of HEV replication and cross-species infection.

\subsection{Chickens}

A chicken model of HEV infection has been developed that presents some advantages: first, like swine HEV, avian HEV is genetically and antigenically related to human HEV [26]. The genomic organisation is very similar to mammalian HEVs. Moreover, avian HEV can be associated with a hepatic disease (HS syndrome). However, in the field, cases of avian HEV infection are mainly subclinical and the pathogenicity linked to avian HEV does not seem to be strain-dependent [87]. SPF chickens can be readily infected by the natural faecal oral route [88] and mild gross pathological lesions and microscopic liver lesions characteristics of HS syndrome have been observed, making it a homologous animal model system to study HEV pathogenesis and replication. Extrahepatic sites of HEV replication were also identified [89]. Cross-species transmission of chicken HEV to turkeys was demonstrated [90]. Infectious cDNA clones of avian HEV were also constructed and capped RNA transcript were used to infect SPF chickens [91-94], allowing to study in vivo the role of particular regions of the HEV genome in viral replication and pathogenesis.

\subsection{Rabbits}

Infection of SPF rabbits with rabbit HEV induces virus shedding in faeces, viremia and the development of hepatitis, characterised by histopathological changes and an increase in the level of ALT in the serum [95-97]. In addition, chronic hepatitis, characterised by liver inflammation and some degree of fibrosis, was observed in rabbits experimentally infected with rabbit HEV [95]. HEV antigen and RNA were found in extrahepatic tissues in infected rabbits [98] and high mortality and vertical transmission of HEV in pregnant rabbits was demonstrated [99]. However, similarly to the swine model, rabbit HEV induces only a subclinical infection with little or no sign of disease. The rabbit model may be useful to study HEV infection and pathogenesis caused by the rabbit strain of HEV and for vaccine evaluation [95]. Experimental infection of rabbits with human HEV genotype 1 or 4 led to the development of hepatitis in none of the rabbits inoculated with HEV-1 and in seven out of nine rabbits inoculated with HEV-4 although most of the inoculated rabbits seroconverted [97]. Rabbits were successfully infected with swine HEV-4 [61] and SPF rabbits farmed in the same enclosed space as HEV-infected pigs seroconverted [100].

\subsection{Rats}

Rodents have been widely used as animal models in scientific and medical research into parasitic, bacterial and viral diseases. Indeed, rodents are easy to handle, manipulate, house and can be used in great numbers. Infection of Wistar rats (via the intravenous or faecal-oral route) with HEV derived from wild rats, can lead to seroconversion and excretion of rat HEV in stool [101]. However, no change in weight and liver enzyme level was observed. The inoculation of Wistar rats with a human stool suspension known to contain HEV-1, led to a successful infection characterised by virus shedding in the faeces, viremia and histopathological changes in the liver, spleen and lymph nodes [102]. However, in two other reports, the injection of HEV-1, $-2,-3$ (swine) and -4 (wild boar) failed to induce an efficient 
infection in Sprague-Dawley or Wistar rats [101,103]. Rats were also inoculated with different RNA transcripts from infectious cDNA clones of rat HEV [104], HEV-4 [105] and swine HEV-3 [106] leading to successful infections. Moreover, attempts to infect Wistar and nude rats with ferret HEV failed [78]. The utility of rats as a model of HEV infection still remains to be demonstrated.

\subsection{Ferrets}

Very recently, two ferrets were inoculated orally with ferret HEV [107], leading to a successful infection characterised by the detection of viral RNA in the stool and the sera, seroconversion and a significant elevation of the liver enzyme ALT. These findings indicate that ferret HEV infection can induce liver damage and ultimately acute hepatitis in ferrets. This suggests that ferrets can be used as a potential animal model to study HEV infection. However, strains naturally infecting this species are close to rat HEV and distant from viruses infecting humans and their use might not be adapted to test antivirals or vaccines.

The limited availability, difficulties in handling, manipulating, housing and the cost of both primates and swine severely restrict their use in large number in research. Moreover, naturally occurring small animal models have shown limits in their use to understand HEV pathogenesis and transmission using human strains. Efforts have then been made to develop alternative small animal models that are not natural hosts of HEV.

\subsection{Mongolian Gerbils}

Mongolian gerbil (Meriones unguiculatus) is a common experimental gerbil species that was also suggested as an alternative animal model to study HEV replication and pathogenesis. Indeed, Mongolian gerbils have been successfully infected via the intraperitonal route with a HEV-4 strain recovered from a swine liver sample $[108,109]$. In addition to viremia and faecal virus shedding, the virus was detected in the liver, kidney and spleen as well as the small intestine. Moreover, characteristic histopathological changes observed in the liver of infected gerbils were similar to those reported in humans, and the liver enzymes ALT, aspartate transaminase (AST) and bilirubin levels in the sera were significantly increased. Finally, HEV RNA was detected in the liver from seven to 42 days post infection, which is consistent with the last days of HEV RNA detection in the swine model [110], suggesting that HEV RNA replication in the Mongolian gerbil is similar to its replication in the swine model. Using this model, a study has also shown that swine HEV-4 is able to cross the blood-brain barrier and replicate in the brain and the spinal cord after experimental infection [111]. Mongolian gerbils could then be useful to study the neurological disorders associated with HEV infection. In addition, a successful infection of Mongolian gerbils with a human HEV-1 strain isolated from an acute hepatitis E patient has been obtained [112]. HEV RNA was detected in the faeces of the infected gerbils and histopathological changes in the liver, spleen and kidney were reported as well as fatigue and hair loss. Mongolian gerbils seem to be a promising model to study HEV-1 and -4 infection and pathogenesis.

\subsection{Human Liver Chimeric Mice}

Mouse is a small animal model that is used as a model for many viral infections. The first attempt to infect C57BL/ 6 mice with HEV-1, HEV-3 and HEV-4 strains failed [113]. In another study, $\mathrm{balb} / \mathrm{c}$ nude mice were inoculated with swine HEV-4 and HEV antigens were detected in the liver as well as in different extrahepatic organs. Moreover, histopathological changes in the liver and the spleen and increased levels of liver enzymes were observed [114]. However, as reported for pigs, the inoculated mice showed no clinical signs of HEV infection. Very recently, human liver chimeric mice were developed [115]. The liver of UPA/SCID mice was repopulated with primary human hepatocytes and the animals were inoculated with stool-derived virions from humans infected with HEV-1 or -3. Viremia and faecal excretion were reported. Moreover, the co-housing of an HEV-infected mouse with three naïve humanized mice led to successful HEV infection, demonstrating that HEV infection can be transmitted through the faecal oral route in humanized mice, direct physical contact or 
micro-injuries [115]. HEV-inoculated human liver chimeric mice were also shown to develop chronic HEV infection $[116,117]$ and the treatment of HEV-infected humanised mice with ribavirin led to a statistically significant decrease in the level of HEV RNA in the serum and the faeces and in no more liver damage $[115,116]$. The human liver chimeric mouse model seems then to be a valuable tool to study the biology of chronic HEV infection and evaluate preclinical drugs. However, this model does not allow immunopathogenesis studies involving adaptive immune responses. Further refinements, such as the transfer of immune cells, may in part overcome these limitations in the future.

Much effort has then been made recently to develop small animal models to study HEV pathogenesis and inter-species transmission. Mongolian gerbils seem to be a promising model that is easy to handle, cost-effective and can mimic hepatic diseases. However, more studies need to be performed to determine whether this species is susceptible to other genotypes of HEV such as HEV-3 and HEV-7. It is also not clear whether gerbils can be infected via the faecal-oral route and whether transmission studies can be performed in this model. Naturally occurring models such as ferrets could also represent a good alternative. Nevertheless, their susceptibility to human and other HEV strains from the Orthohepevirus A species remains to be determined. The identification of new strains and hosts of HEV might help in the near future to the development of a suitable naturally occurring animal model.

\section{Inter-Species Transmission of HEV}

As described above, animal models and HEV natural reservoirs have been used to study experimentally the interspecies transmission of different HEV species and genotypes. The results obtained from these different studies are summarised in Figure 3. They clearly show that HEV-1 and HEV-2 are restricted to humans whereas HEV-3 and HEV-4 are naturally present in several animal species and can cross the species barrier. This difference raises the question of species barrier determinants. Several studies have suggested that genetic elements present in HEV ORF1 are involved in species barrier crossing [118-121].

In addition, the zoonotic transmission of HEV-3 and HEV-4 from swine, wild boar and deer to human via the consumption of contaminated meat has been proven. Molecular and phylogenetic analyses of HEV-3 and HEV-4 sequences from human and pig origin have shown high identity between the two populations and the absence of species clustering [49]. This suggests that swine HEV-3 and HEV-4 may not require any adaptation to jump between these two species. A study showing that the consensus sequence of HEV-3 is identical during transmission from human to swine is in agreement with this hypothesis [122]. However, it is still unclear whether strains of HEV-3 and HEV-4 present in other animals can cross the species barrier and infect humans. For example, the ability of rabbit HEV to infect humans and its contribution to zoonotic hepatitis $\mathrm{E}$ infection remain to be determined. The successful infection of cynomolgus macaques with rabbit HEV suggests that inter-species transmission of rabbit HEV-3 to human is possible [78]. The identification of a human strain that is closely related to rabbit strains is also in agreement with this hypothesis [51]. Further studies are also needed to determine the risk of zoonotic transmission of other strains from the Orthohepevirus A species such as wild boar HEV-5 and HEV-6. In addition, the recent identification of a human case associated with HEV-7 strongly suggests that this genotype is transmissible from camels to humans [54]. However, the contribution of HEV-7 to zoonotic hepatitis E remains to be clarified. Since zoonotic genotypes such as HEV-3 and HEV-4 can infect multiple animal species, it is also important to determine experimentally whether HEV-7 can infect other species such as rabbit and swine. This will help to clarify whether second or new reservoirs of this potential zoonotic genotype might exist or appear through direct transmission from camels or through human intervention. 


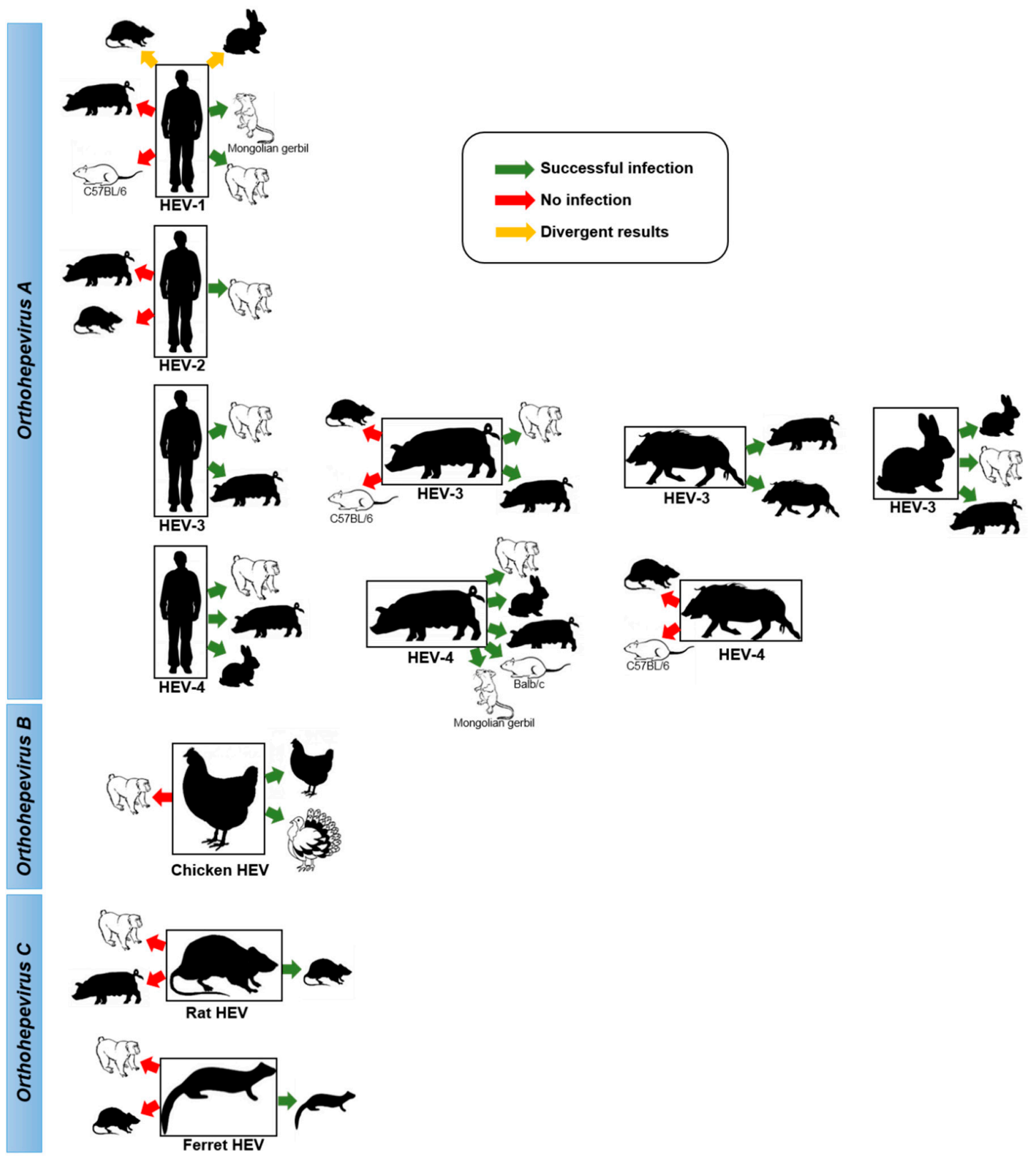

Figure 3. Experimental inter-species transmissions of HEV. Inter-species transmission of different HEV strains determined by the experimental infection of animal reservoirs (black silhouette) or animal models (white silhouette). Details and references of the different experiments presented are given in the text.

\section{Transmission Pathways of Zoonotic HEV}

Since the discovery of swine HEV in 1997 [10], the risk of zoonotic transmission of HEV has been questioned and concern for public health has been raised. The first direct evidence of zoonotic transmission of HEV to humans was provided six years later following cases of HEV infection among patients who had consumed sashimi of Sika deer [123]. HEV-3 RNA was retrieved from the left-over deer meat and its sequence was found to be identical to those from the patients ( $326 \mathrm{nt}$ within HEV ORF1). Three case reports have then provided additional direct evidence that HEV is a zoonosis that can be transmitted via the consumption of contaminated food. In these studies, identical or near identical HEV sequences were detected in patients suffering from hepatitis $\mathrm{E}$ and animal products they had consumed: grilled wild boar meat in Japan [124], pig meat in Spain [125] and ficatellu sausage 
from Corsica [126]. Several reports in Japan, France, Spain and Australia have also linked sporadic cases or outbreaks of hepatitis $\mathrm{E}$ with the consumption of raw or undercooked pork or wild boar products (meat, liver, liver paté, ficatellu or liver-based stuffing) without direct proof that these food items were the source of the infection [126-133]. These data are supported by studies showing that the consumption of pork and wild-boar meat and processed products is a risk factor for autochthonous HEV infection and HEV seropositivity [129,134-138]. In one of these studies, consumption of offal and wild-boar meat was found to be associated with autochthonous HEV infection in Germany [134]. Eating pork meat, pork liver sausages, game meat and offal was also found as a major contributor to the presence of anti-HEV antibodies in a recent nationwide survey performed in France [135].

HEV-3 and HEV-4 RNA is present throughout the pork food chain worldwide [130,133,139-143]. Studies have reported that $3 \%-11 \%$ of pig liver samples at the slaughterhouse are HEV positive in France (4\%) [144], the Netherlands (6.5\%) [145], Czech Republic (5\%) [141], Italy (6\%) [140], Spain (3\%) [140], the United Kingdom (3\%) [146], Japan (5\%) [147] and the US (11\%) [148]. HEV RNA was also found in the liver of wild boars (5.8\%), deer (3.2\%) and wild rabbits $(5 \%)$ hunted in southwestern France [149] and in the liver of wild boars (1.9\%) hunted in north-western Italy [150]. HEV RNA has also been detected in pork sausages sold in the UK (10\%) [146] and in Spain (6\%) [140]; in ficatelli $(30 \%)$, dried salted liver (3\%), quenelle and quenelle paste $(25 \%)$ and dried or fresh liver sausages $(29 \%)$ sold in France [139]; in raw and dry liver sausages purchased in Italy [141], in raw sausages $(20 \%)$ and liver sausages (22\%) sold in Germany [142]; and in pork pâté and blood sausage (36\%) sold in Brazil [151].

Several studies have shown that such commercially-available pork livers and pork-derived products containing raw liver can contain infectious virus and are potential sources of foodborne HEV. Pigs inoculated intravenously with homogenates from contaminated pig livers sold in grocery stores in the United States became infected with HEV [148]. Moreover, HEV was successfully cultured in human cell lines inoculated with extracts from ficatelli sausages produced in France [152] or raw porcine liver purchased from grocery stores in Japan [153].

Recently, a liver-transplant patient from the Middle East who regularly consumed camel meat and milk was found to be infected with camelid HEV-7 [54]. Other animal reservoirs and genotypes of HEV might then be involved in the foodborne transmission of HEV. Milk from HEV-infected animals could also represent another source of zoonotic HEV that need to be further investigated.

Other foods that are not derived from animal products can be contaminated with HEV and are possible sources of foodborne HEV transmission. For instance, HEV-3 or HEV-4 RNA has been found in mussels from Galicia (14.81\%) [154] and Scotland (85\%) [155]; in oysters from coastal regions in Korea (8.7\%) [156]; in bivalves from Japanese rivers [157]; and in shellfish from the coastal waters of China [158]. Moreover, experimental bioaccumulation has shown that oysters, flat oysters, mussels and clams can concentrate HEV, mostly in their digestive tissues [159]. Transmission of zoonotic HEV to human via the consumption of seafood has not been proven directly yet as no identical or near identical HEV sequences have been retrieved in patients suffering from hepatitis $E$ and the seafood they had consumed. However, the consumption of shellfish has been strongly linked to an imported case of HEV-4 infection in a Japanese patient who travelled to Vietnam [160] and to an outbreak of hepatitis E on a cruise ship (HEV-3) [161].

In addition, HEV RNA has been found in strawberries in Canada [162], in frozen raspberries sold in Europe [163] and in the salad vegetable supply chain in Europe [164], suggesting that soft fruits and vegetables can also be contaminated with HEV RNA. A study has also suggested that herbs and spices can be contaminated with HEV $(0.9 \%)$ [165].

The presence of HEV in shellfish, vegetable and fruits is likely caused by the contamination of surface and irrigation water with animal sewage. HEV RNA has been detected in swine sewage and manure worldwide $[133,166-169]$ and it was shown that such waste products can be infectious when inoculated experimentally to pigs [169]. Runoff or insufficient treatment of sewage water from pig farms and use of manure as soil fertiliser could then lead to the contamination of neighbouring surface 
water. This hypothesis is supported by studies that found HEV RNA in surface water in proximity of pig farms [170,171]. HEV sequences similar to sequences found in patients with autochthonous hepatitis E infection and in swine have also been repeatedly found in river and seawater [172-174]. In addition, some of the shellfish found to be HEV RNA positive in Scotland were harvested near a slaughterhouse and pork processing plant [118].

The presence of HEV in food products derived from natural reservoirs of zoonotic HEV or food that are contaminated by surface and irrigation water raises concerns for public health and food safety worldwide. A subunit vaccine based on the expression of a truncated viral capsid is able to confer full protection after three doses and is licensed in China [175]. However, such vaccine has not yet been approved and commercialised in other countries. Prevention of zoonotic HEV relies mainly on avoiding raw and undercooked meat or selfish and cooking meat and meat products thoroughly. A few studies have been conducted using cell-culture [176,177] or in vivo swine experimental models $[178,179]$ to determine the stability of HEV in the environment and in food products. Infectious viruses are still present in faecal suspension or cell-culture supernatant after heating at $56-60{ }^{\circ} \mathrm{C}[176,177]$. Efficient inactivation of HEV in food products derived from infected pork liver was only achieved after a cooking time of at least $20 \mathrm{~min}$ at an internal temperature of $71^{\circ} \mathrm{C}[178,179]$. Temperatures equivalent to rare and medium-to-rare cooking are then insufficient to inactivate the virus and cooking food thoroughly and evenly is highly recommended to prevent foodborne transmission of HEV. Appropriate hygiene measures such as frequent hand and surface cleaning should also been followed when handling uncooked meat. In addition, swine waste should be properly eliminated and the use of swine manure as soil fertiliser should be regulated to reduce the risk of HEV contamination of crops and surface water.

As described above, HEV RNA has been detected in diverse food products ranging from meat and seafood, to fruits and vegetables. However, it is still unclear whether infectious lived virus can be present in most of these items. To solve this issue, a robust cell culture system needs to be developed rapidly. Such model will also help to clarify whether infectious viruses can be present in pork products that contain no liver such as cured ham. Indeed, the high HEV seroprevalence in human found in some countries such as France (22.4\%) [135] cannot be explained only by the consumption of products containing raw pork liver such as ficatelli. Efforts are also needed to establish standardized methods to ensure a quality control of products at risk and the HEV oral-infectious dose remained to be determined to perform risk assessment studies.

In addition to foodborne routes of transmission, seroprevalence studies have suggested that direct contacts with infected animal reservoirs are risk factors for HEV exposure. Higher seroprevalence of anti-HEV antibodies was found in swine workers and veterinarians in the United States [180,181]; in swine veterinarians in France [137] and the Netherlands [145]; in swine farmers in Sweden [182], France [137] and Moldovia [183]; and in pork butchers in Burkina Faso [184]. In addition, higher HEV seroprevalence was detected among French hunters [100] and among forestry workers in France [137,185] and Germany [186]. The presence of stools from infected wild animals in forest may represent a source of contamination for this population. Interestingly, simple prevention measures such as wearing gloves and wearing boots for pig farmers, forestry workers or hunters are associated with reduced risk of HEV exposure [137,187]. A cross-sectional survey conducted in China has also found a higher anti-HEV IgG seroprevalence in seafood processing workers who have direct contacts with raw seafood [188]. Direct contacts with contaminated food and water might then represent a risk of HEV infection.

Contact with pet pig might also represent a possible source of HEV infection. In one study, frequent contact with a pet pig was reported to be the most likely cause of contamination of a French patient with acute hepatitis E [189]. 


\section{Conclusions}

Many novel strains of HEV have been identified in the last decades in diverse animal species. These discoveries have led to the reviewing of the Hepeviridae family classification and the ratification by the ICTV of a new taxonomic structure [8]. Nevertheless, it is very likely that additional HEV variants exist and that this classification will further evolve in the future. Available diagnostic tools are based on identified HEV strains and are probably not able to detect all the existing HEV strains. It is essential then that new molecular techniques are designed rapidly to detect a larger diversity of HEV strains and hosts. The wider use of metagenomics and deep sequencing could also contribute to the identification of HEV variants. Swine have been studied as the main HEV reservoir since its discovery in the late 1990s and HEV screenings in food have focussed mainly on pork-derived meat and meat products. However, it is possible that other animal reservoirs representing a significant risk for the zoonotic transmission of HEV exist. More studies are then clearly needed to screen a larger variety of food products derived from diverse animal species, including rabbit, camel and many others for the presence of HEV RNA and infectious virus. An exhaustive understanding of the extent of the animal reservoirs and transmission routes representing a risk for zoonotic hepatitis $\mathrm{E}$ infection is essential to prevent and control efficiently the disease in the future.

Acknowledgments: Studies conducted on HEV by Nicole Pavio are supported by the European Union Seventh Framework Program (FP7/2007-2013) under Grant Agreement No. 278433-PREDEMICS.

Conflicts of Interest: The authors declare no conflict of interest.

\section{References}

1. Kamar, N.; Marion, O.; Abravanel, F.; Izopet, J.; Dalton, H.R. Extrahepatic manifestations of hepatitis E virus. Liver Int. 2016, 36, 467-472. [CrossRef] [PubMed]

2. Sayed, I.M.; Vercouter, A.-S.; Abdelwahab, S.F.; Vercauteren, K.; Meuleman, P. Is hepatitis E virus an emerging problem in industrialized countries? Hepatology 2015, 62, 1883-1892. [CrossRef] [PubMed]

3. Murali, A.R.; Kotwal, V.; Chawla, S. Chronic hepatitis E: A brief review. World J. Hepatol. 2015, 7, $2194-2201$. [CrossRef] [PubMed]

4. Khuroo, M.S. Study of an epidemic of non-A, non-B hepatitis. Possibility of another human hepatitis virus distinct from post-transfusion non-A, non-B type. Am. J. Med. 1980, 68, 818-824. [CrossRef]

5. Balayan, M.S.; Andjaparidze, A.G.; Savinskaya, S.S.; Ketiladze, E.S.; Braginsky, D.M.; Savinov, A.P.; Poleschuk, V.F. Evidence for a virus in non-A, non-B hepatitis transmitted via the fecal-oral route. Intervirology 1983, 20, 23-31. [PubMed]

6. Reyes, G.R.; Purdy, M.A.; Kim, J.P.; Luk, K.C.; Young, L.M.; Fry, K.E.; Bradley, D.W. Isolation of a cDNA from the virus responsible for enterically transmitted non-A, non-B hepatitis. Science 1990, 247, 1335-1339. [CrossRef] [PubMed]

7. Tam, A.W.; Smith, M.M.; Guerra, M.E.; Huang, C.C.; Bradley, D.W.; Fry, K.E.; Reyes, G.R. Hepatitis E virus (HEV): Molecular cloning and sequencing of the full-length viral genome. Virology 1991, 185, 120-131. [CrossRef]

8. Smith, D.B.; Simmonds, P.; Jameel, S.; Emerson, S.U.; Harrison, T.J.; Meng, X.-J.; Okamoto, H.; Van der Poel, W.H.M.; Purdy, M.A.; et al. Consensus proposals for classification of the family Hepeviridae. J. Gen. Virol. 2014, 95, 2223-2232. [CrossRef] [PubMed]

9. Clayson, E.T.; Innis, B.L.; Myint, K.S.; Narupiti, S.; Vaughn, D.W.; Giri, S.; Ranabhat, P.; Shrestha, M.P. Detection of hepatitis E virus infections among domestic swine in the Kathmandu Valley of Nepal. Am. J. Trop. Med. Hyg. 1995, 53, 228-232. [PubMed]

10. Meng, X.J.; Purcell, R.H.; Halbur, P.G.; Lehman, J.R.; Webb, D.M.; Tsareva, T.S.; Haynes, J.S.; Thacker, B.J.; Emerson, S.U. A novel virus in swine is closely related to the human hepatitis E virus. Proc. Natl. Acad. Sci. USA 1997, 94, 9860-9865. [CrossRef] [PubMed]

11. Halbur, P.G.; Kasorndorkbua, C.; Gilbert, C.; Guenette, D.; Potters, M.B.; Purcell, R.H.; Emerson, S.U.; Toth, T.E.; Meng, X.J. Comparative pathogenesis of infection of pigs with hepatitis E viruses recovered from a pig and a human. J. Clin. Microbiol. 2001, 39, 918-923. [CrossRef] [PubMed] 
12. Pavio, N.; Meng, X.-J.; Renou, C. Zoonotic hepatitis E: Animal reservoirs and emerging risks. Vet. Res. 2010, 41, 46. [CrossRef] [PubMed]

13. Pavio, N.; Meng, X.-J.; Doceul, V. Zoonotic origin of hepatitis E. Curr. Opin. Virol. 2015, 10, 34-41. [CrossRef] [PubMed]

14. Yugo, D.M.; Meng, X.-J. Hepatitis E virus: Foodborne, waterborne and zoonotic transmission. Int. J. Environ. Res. Public. Health 2013, 10, 4507-4533. [CrossRef] [PubMed]

15. Li, T.-C.; Saito, M.; Ogura, G.; Ishibashi, O.; Miyamura, T.; Takeda, N. Serologic evidence for hepatitis E virus infection in mongoose. Am. J. Trop. Med. Hyg. 2006, 74, 932-936. [PubMed]

16. Nakamura, M.; Takahashi, K.; Taira, K.; Taira, M.; Ohno, A.; Sakugawa, H.; Arai, M.; Mishiro, S. Hepatitis E virus infection in wild mongooses of Okinawa, Japan: Demonstration of anti-HEV antibodies and a full-genome nucleotide sequence. Hepatol. Res. 2006, 34, 137-140. [CrossRef] [PubMed]

17. Nidaira, M.; Takahashi, K.; Ogura, G.; Taira, K.; Okano, S.; Kudaka, J.; Itokazu, K.; Mishiro, S.; Nakamura, M. Detection and phylogenetic analysis of hepatitis E viruses from mongooses in Okinawa, Japan. J. Vet. Med. Sci. 2012, 74, 1665-1668. [CrossRef] [PubMed]

18. Zhao, C.; Ma, Z.; Harrison, T.J.; Feng, R.; Zhang, C.; Qiao, Z.; Fan, J.; Ma, H.; Li, M.; Song, A.; Wang, Y. A novel genotype of hepatitis $\mathrm{E}$ virus prevalent among farmed rabbits in China. J. Med. Virol. 2009, 81, 1371-1379. [CrossRef] [PubMed]

19. Cossaboom, C.M.; Córdoba, L.; Dryman, B.A.; Meng, X.-J. Hepatitis E virus in rabbits, Virginia, USA. Emerg. Infect. Dis. 2011, 17, 2047-2049. [CrossRef] [PubMed]

20. Lhomme, S.; Dubois, M.; Abravanel, F.; Top, S.; Bertagnoli, S.; Guerin, J.-L.; Izopet, J. Risk of zoonotic transmission of HEV from rabbits. J. Clin. Virol. 2013, 58, 357-362. [CrossRef] [PubMed]

21. Caruso, C.; Modesto, P.; Prato, R.; Scaglione, F.E.; De Marco, L.; Bollo, E.; Acutis, P.L.; Masoero, L.; Peletto, S. Hepatitis E Virus: First description in a pet house rabbit. A new transmission route for human? Transbound. Emerg. Dis. 2015, 62, 229-232. [CrossRef] [PubMed]

22. Takahashi, M.; Nishizawa, T.; Sato, H.; Sato, Y.; Jirintai; Nagashima, S.; Okamoto, H. Analysis of the full-length genome of a hepatitis E virus isolate obtained from a wild boar in Japan that is classifiable into a novel genotype. J. Gen. Virol. 2011, 92, 902-908. [CrossRef] [PubMed]

23. Woo, P.C.Y.; Lau, S.K.P.; Teng, J.L.L.; Tsang, A.K.L.; Joseph, M.; Wong, E.Y.M.; Tang, Y.; Sivakumar, S.; Xie, J.; Bai, R.; Wernery, R.; et al. New hepatitis E virus genotype in camels, the Middle East. Emerg. Infect. Dis. 2014, 20, 1044-1048. [CrossRef] [PubMed]

24. Lin, J.; Karlsson, M.; Olofson, A.-S.; Belák, S.; Malmsten, J.; Dalin, A.-M.; Widén, F.; Norder, H. High prevalence of hepatitis e virus in Swedish moose-A phylogenetic characterization and comparison of the virus from different regions. PLoS ONE 2015, 10, e0122102. [CrossRef] [PubMed]

25. Haqshenas, G.; Shivaprasad, H.L.; Woolcock, P.R.; Read, D.H.; Meng, X.J. Genetic identification and characterization of a novel virus related to human hepatitis $\mathrm{E}$ virus from chickens with hepatitis-splenomegaly syndrome in the United States. J. Gen. Virol. 2001, 82, 2449-2462. [CrossRef] [PubMed]

26. Payne, C.J.; Ellis, T.M.; Plant, S.L.; Gregory, A.R.; Wilcox, G.E. Sequence data suggests big liver and spleen disease virus (BLSV) is genetically related to hepatitis E virus. Vet. Microbiol. 1999, 68, 119-125. [CrossRef]

27. Huang, F.F.; Haqshenas, G.; Shivaprasad, H.L.; Guenette, D.K.; Woolcock, P.R.; Larsen, C.T.; Pierson, F.W.; Elvinger, F.; Toth, T.E.; Meng, X.J. Heterogeneity and seroprevalence of a newly identified avian hepatitis e virus from chickens in the United States. J. Clin. Microbiol. 2002, 40, 4197-4202. [CrossRef] [PubMed]

28. Johne, R.; Heckel, G.; Plenge-Bönig, A.; Kindler, E.; Maresch, C.; Reetz, J.; Schielke, A.; Ulrich, R.G. Novel hepatitis E virus genotype in Norway rats, Germany. Emerg. Infect. Dis. 2010, 16, 1452-1455. [CrossRef] [PubMed]

29. Raj, V.S.; Smits, S.L.; Pas, S.D.; Provacia, L.B. V.; Moorman-Roest, H.; Osterhaus, A.D. M.E.; Haagmans, B.L. Novel Hepatitis E Virus in Ferrets, The Netherlands. Emerg. Infect. Dis. 2012, 18, 1369-1370. [CrossRef] [PubMed]

30. Krog, J.S.; Breum, S.Ø.; Jensen, T.H.; Larsen, L.E. Hepatitis E Virus variant in farmed mink, Denmark. Emerg. Infect. Dis. 2013, 19, 2028-2030. [CrossRef] [PubMed]

31. Bodewes, R.; van der Giessen, J.; Haagmans, B.L.; Osterhaus, A.D.M.E.; Smits, S.L. Identification of multiple novel viruses, including a parvovirus and a hepevirus, in feces of red foxes. J. Virol. 2013, 87, 7758-7764. [CrossRef] [PubMed]

32. Drexler, J.F.; Seelen, A.; Corman, V.M.; Tateno, A.F.; Cottontail, V.; Zerbinati, R.M.; Gloza-Rausch, F.; Klose, S.M.; Adu-Sarkodie, Y.; Oppong, S.K.; et al. Bats worldwide carry hepatitis E virus-related viruses 
that form a putative novel genus within the family Hepeviridae. J. Virol. 2012, 86, 9134-9147. [CrossRef] [PubMed]

33. Reuter, G.; Boros, Á.; Mátics, R.; Kapusinszky, B.; Delwart, E.; Pankovics, P. Divergent hepatitis E virus in birds of prey, common kestrel (Falco tinnunculus) and red-footed falcon (F. vespertinus), Hungary. Infect. Genet. Evol. 2016, 43, 343-346. [CrossRef] [PubMed]

34. Batts, W.; Yun, S.; Hedrick, R.; Winton, J. A novel member of the family Hepeviridae from cutthroat trout (Oncorhynchus clarkii). Virus Res. 2011, 158, 116-123. [CrossRef] [PubMed]

35. Vina-Rodriguez, A.; Schlosser, J.; Becher, D.; Kaden, V.; Groschup, M.H.; Eiden, M. Hepatitis E virus genotype 3 diversity: Phylogenetic analysis and presence of subtype $3 \mathrm{~b}$ in wild boar in Europe. Viruses 2015, 7, 2704-2726. [CrossRef] [PubMed]

36. Oliveira-Filho, E.F.; König, M.; Thiel, H.-J. Genetic variability of HEV isolates: Inconsistencies of current classification. Vet. Microbiol. 2013, 165, 148-154. [CrossRef] [PubMed]

37. Mirazo, S.; Mir, D.; Bello, G.; Ramos, N.; Musto, H.; Arbiza, J. New insights into the hepatitis E virus genotype 3 phylodynamics and evolutionary history. Infect. Genet. Evol. 2016, 43, 267-273. [CrossRef] [PubMed]

38. Smith, D.B.; Simmonds, P.; Izopet, J.; Oliveira-Filho, E.F.; Ulrich, R.G.; Johne, R.; Koenig, M.; Jameel, S.; Harrison, T.J.; Meng, X.-J.; et al. Proposed reference sequences for hepatitis E virus subtypes. J. Gen. Virol. 2016, 97, 537-542. [CrossRef] [PubMed]

39. Lu, L.; Li, C.; Hagedorn, C.H. Phylogenetic analysis of global hepatitis E virus sequences: Genetic diversity, subtypes and zoonosis. Rev. Med. Virol. 2006, 16, 5-36. [CrossRef] [PubMed]

40. Zehender, G.; Ebranati, E.; Lai, A.; Luzzago, C.; Paladini, S.; Tagliacarne, C.; Galli, C.; Galli, M.; Ciccozzi, M.; Zanetti, A.R.; et al. Phylogeography and phylodynamics of European genotype 3 hepatitis E virus. Infect. Genet. Evol. 2014, 25, 138-143. [CrossRef] [PubMed]

41. Huang, C.C.; Nguyen, D.; Fernandez, J.; Yun, K.Y.; Fry, K.E.; Bradley, D.W.; Tam, A.W.; Reyes, G.R. Molecular cloning and sequencing of the Mexico isolate of hepatitis E virus (HEV). Virology 1992, 191, 550-558. [CrossRef]

42. Buisson, Y.; Grandadam, M.; Nicand, E.; Cheval, P.; van Cuyck-Gandre, H.; Innis, B.; Rehel, P.; Coursaget, P.; Teyssou, R.; Tsarev, S. Identification of a novel hepatitis E virus in Nigeria. J. Gen. Virol. 2000, 81, 903-909. [CrossRef] [PubMed]

43. Nicand, E.; Armstrong, G.L.; Enouf, V.; Guthmann, J.P.; Guerin, J.-P.; Caron, M.; Nizou, J.Y.; Andraghetti, R. Genetic heterogeneity of hepatitis E virus in Darfur, Sudan, and neighboring Chad. J. Med. Virol. 2005, 77, 519-521. [CrossRef] [PubMed]

44. Ijaz, S.; Said, B.; Boxall, E.; Smit, E.; Morgan, D.; Tedder, R.S. Indigenous hepatitis E in England and wales from 2003 to 2012: Evidence of an emerging novel phylotype of viruses. J. Infect. Dis. 2014, 209, 1212-1218. [CrossRef] [PubMed]

45. Smith, D.B.; Ijaz, S.; Tedder, R.S.; Hogema, B.; Zaaijer, H.L.; Izopet, J.; Bradley-Stewart, A.; Gunson, R.; Harvala, H.; Kokki, I.; Simmonds, P. Variability and pathogenicity of hepatitis E virus genotype 3 variants. J. Gen. Virol. 2015, 96, 3255-3264. [CrossRef] [PubMed]

46. Purdy, M.A.; Khudyakov, Y.E. Evolutionary history and population dynamics of hepatitis E virus. PLoS ONE 2010, 5, e14376. [CrossRef] [PubMed]

47. Teo, C.-G. Fatal outbreaks of jaundice in pregnancy and the epidemic history of hepatitis E. Epidemiol. Infect. 2012, 140, 767-787. [CrossRef] [PubMed]

48. Pei, Y.; Yoo, D. Genetic characterization and sequence heterogeneity of a Canadian isolate of Swine hepatitis E virus. J. Clin. Microbiol. 2002, 40, 4021-4029. [CrossRef] [PubMed]

49. Bouquet, J.; Tesse, S.; Lunazzi, A.; Eloit, M.; Rose, N.; Nicand, E.; Pavio, N. Close similarity between sequences of hepatitis E virus recovered from humans and swine, France, 2008-2009. Emerg. Infect. Dis. 2011, 17, 2018-2025. [CrossRef] [PubMed]

50. Lhomme, S.; Abravanel, F.; Dubois, M.; Chapuy-Regaud, S.; Sandres-Saune, K.; Mansuy, J.-M.; Rostaing, L.; Kamar, N.; Izopet, J. Temporal evolution of the distribution of hepatitis E virus genotypes in Southwestern France. Infect. Genet. Evol. 2015, 35, 50-55. [CrossRef] [PubMed]

51. Izopet, J.; Dubois, M.; Bertagnoli, S.; Lhomme, S.; Marchandeau, S.; Boucher, S.; Kamar, N.; Abravanel, F.; Guérin, J.-L. Hepatitis E virus strains in rabbits and evidence of a closely related strain in humans, France. Emerg. Infect. Dis. 2012, 18, 1274-1281. [CrossRef] [PubMed] 
52. Wu, J.; Si, F.; Jiang, C.; Li, T.; Jin, M. Molecular detection of hepatitis E virus in sheep from southern Xinjiang, China. Virus Genes 2015, 50, 410-417. [CrossRef] [PubMed]

53. Huang, F.; Li, Y.; Yu, W.; Jing, S.; Wang, J.; Long, F.; He, Z.; Yang, C.; Bi, Y.; Cao, W.; et al. Excretion of infectious hepatitis E virus into milk in cows imposes high risks of zoonosis. Hepatology 2016, 64, 350-359. [CrossRef] [PubMed]

54. Lee, G.-H.; Tan, B.-H.; Teo, E.C.-Y.; Lim, S.-G.; Dan, Y.-Y.; Wee, A.; Aw, P.P.K.; Zhu, Y.; Hibberd, M.L.; Tan, C.-K.; et al. Chronic infection with camelid hepatitis $\mathrm{E}$ virus in a liver transplant recipient who regularly consumes camel meat and milk. Gastroenterology 2016, 150, 355-357. [CrossRef] [PubMed]

55. Huang, F.F.; Sun, Z.F.; Emerson, S.U.; Purcell, R.H.; Shivaprasad, H.L.; Pierson, F.W.; Toth, T.E.; Meng, X.J. Determination and analysis of the complete genomic sequence of avian hepatitis E virus (avian HEV) and attempts to infect rhesus monkeys with avian HEV. J. Gen. Virol. 2004, 85, 1609-1618. [CrossRef] [PubMed]

56. Bilic, I.; Jaskulska, B.; Basic, A.; Morrow, C.J.; Hess, M. Sequence analysis and comparison of avian hepatitis E viruses from Australia and Europe indicate the existence of different genotypes. J. Gen. Virol. 2009, 90, 863-873. [CrossRef] [PubMed]

57. Hsu, I.W.-Y.; Tsai, H.-J. Avian hepatitis E virus in chickens, Taiwan, 2013. Emerg. Infect. Dis. 2014, 20, $149-151$. [CrossRef] [PubMed]

58. Guan, D.; Li, W.; Su, J.; Fang, L.; Takeda, N.; Wakita, T.; Li, T.-C.; Ke, C. Asian musk shrew as a reservoir of rat hepatitis E virus, China. Emerg. Infect. Dis. 2013, 19, 1341-1343. [CrossRef] [PubMed]

59. Li, W.; Guan, D.; Su, J.; Takeda, N.; Wakita, T.; Li, T.-C.; Ke, C.W. High prevalence of rat hepatitis E virus in wild rats in China. Vet. Microbiol. 2013, 165, 275-280. [CrossRef] [PubMed]

60. Lin, J.; Norder, H.; Uhlhorn, H.; Belák, S.; Widén, F. Novel hepatitis E like virus found in Swedish moose. J. Gen. Virol. 2014, 95, 557-570. [CrossRef] [PubMed]

61. Johne, R.; Dremsek, P.; Reetz, J.; Heckel, G.; Hess, M.; Ulrich, R.G. Hepeviridae: An expanding family of vertebrate viruses. Infect. Genet. Evol. 2014, 27, 212-229. [CrossRef] [PubMed]

62. Vitral, C.L.; Yoshida, C.F.; Gaspar, A.M. The use of non-human primates as animal models for the study of hepatitis viruses. Braz. J. Med. Biol. Res. Rev. 1998, 31, 1035-1048. [CrossRef]

63. Yamamoto, H.; Suzuki, J.; Matsuda, A.; Ishida, T.; Ami, Y.; Suzaki, Y.; Adachi, I.; Wakita, T.; Takeda, N.; Li, T.-C. Hepatitis E virus outbreak in monkey facility, Japan. Emerg. Infect. Dis. 2012, 18, 2032-2034. [CrossRef] [PubMed]

64. Tsarev, S.A.; Tsareva, T.S.; Emerson, S.U.; Rippy, M.K.; Zack, P.; Shapiro, M.; Purcell, R.H. Experimental hepatitis $\mathrm{E}$ in pregnant rhesus monkeys: Failure to transmit hepatitis $\mathrm{E}$ virus (HEV) to offspring and evidence of naturally acquired antibodies to HEV. J. Infect. Dis. 1995, 172, 31-37. [CrossRef] [PubMed]

65. Li, X.; Kamili, S.; Krawczynski, K. Quantitative detection of hepatitis E virus RNA and dynamics of viral replication in experimental infection. J. Viral Hepat. 2006, 13, 835-839. [CrossRef] [PubMed]

66. Erker, J.C.; Desai, S.M.; Schlauder, G.G.; Dawson, G.J.; Mushahwar, I.K. A hepatitis E virus variant from the United States: Molecular characterization and transmission in cynomolgus macaques. J. Gen. Virol. 1999, 80, 681-690. [CrossRef] [PubMed]

67. Ma, H.; Song, X.; Harrison, T.J.; Li, R.; Huang, G.; Zhang, H.; Kong, W.; Wang, Y. Immunogenicity and efficacy of a bacterially expressed HEV ORF3 peptide, assessed by experimental infection of primates. Arch. Virol. 2009, 154, 1641-1648. [CrossRef] [PubMed]

68. Yugo, D.M.; Cossaboom, C.M.; Meng, X.-J. Naturally occurring animal models of human hepatitis E virus infection. ILAR J. 2014, 55, 187-199. [CrossRef] [PubMed]

69. Bradley, D.W.; Krawczynski, K.; Cook, E.H.; McCaustland, K.A.; Humphrey, C.D.; Spelbring, J.E.; Myint, H.; Maynard, J.E. Enterically transmitted non-A, non-B hepatitis: Serial passage of disease in cynomolgus macaques and tamarins and recovery of disease-associated 27- to 34-nm viruslike particles. Proc. Natl. Acad. Sci. USA 1987, 84, 6277-6281. [CrossRef] [PubMed]

70. Krawczynski, K.; Bradley, D.W. Enterically transmitted non-A, non-B hepatitis: Identification of virus-associated antigen in experimentally infected cynomolgus macaques. J. Infect. Dis. 1989, 159, 1042-1049. [CrossRef] [PubMed]

71. Aggarwal, R.; Kamili, S.; Spelbring, J.; Krawczynski, K. Experimental studies on subclinical hepatitis E virus infection in cynomolgus macaques. J. Infect. Dis. 2001, 184, 1380-1385. [CrossRef] [PubMed] 
72. Longer, C.F.; Denny, S.L.; Caudill, J.D.; Miele, T.A.; Asher, L.V.; Myint, K.S.; Huang, C.C.; Engler, W.F.; LeDuc, J.W.; Binn, L.N. Experimental hepatitis E: Pathogenesis in cynomolgus macaques (Macaca fascicularis). J. Infect. Dis. 1993, 168, 602-609. [CrossRef] [PubMed]

73. Tsarev, S.A.; Emerson, S.U.; Tsareva, T.S.; Yarbough, P.O.; Lewis, M.; Govindarajan, S.; Reyes, G.R.; Shapiro, M.; Purcell, R.H. Variation in course of hepatitis E in experimentally infected cynomolgus monkeys. J. Infect. Dis. 1993, 167, 1302-1306. [CrossRef] [PubMed]

74. Purdy, M.A.; McCaustland, K.A.; Krawczynski, K.; Spelbring, J.; Reyes, G.R.; Bradley, D.W. Preliminary evidence that a trpE-HEV fusion protein protects cynomolgus macaques against challenge with wild-type hepatitis E virus (HEV). J. Med. Virol. 1993, 41, 90-94. [CrossRef] [PubMed]

75. Tsarev, S.A.; Tsareva, T.S.; Emerson, S.U.; Govindarajan, S.; Shapiro, M.; Gerin, J.L.; Purcell, R.H. Successful passive and active immunization of cynomolgus monkeys against hepatitis E. Proc. Natl. Acad. Sci. USA 1994, 91, 10198-10202. [CrossRef] [PubMed]

76. Meng, X.J.; Halbur, P.G.; Shapiro, M.S.; Govindarajan, S.; Bruna, J.D.; Mushahwar, I.K.; Purcell, R.H.; Emerson, S.U. Genetic and experimental evidence for cross-species infection by swine hepatitis E virus. J. Virol. 1998, 72, 9714-9721. [PubMed]

77. Arankalle, V.A.; Chobe, L.P.; Chadha, M.S. Type-IV Indian swine HEV infects rhesus monkeys. J. Viral Hepat. 2006, 13, 742-745. [CrossRef] [PubMed]

78. Liu, P.; Bu, Q.-N.; Wang, L.; Han, J.; Du, R.-J.; Lei, Y.-X.; Ouyang, Y.-Q.; Li, J.; Zhu, Y.-H.; Lu, F.-M.; et al. Transmission of hepatitis E virus from rabbits to cynomolgus macaques. Emerg. Infect. Dis. 2013, 19, 559-565. [CrossRef] [PubMed]

79. Li, T.-C.; Yoshizaki, S.; Ami, Y.; Suzaki, Y.; Yang, T.; Takeda, N.; Takaji, W. Monkeys and rats are not susceptible to ferret hepatitis E virus infection. Intervirology 2015, 58, 139-142. [CrossRef] [PubMed]

80. Feagins, A.R.; Opriessnig, T.; Huang, Y.W.; Halbur, P.G.; Meng, X.J. Cross-species infection of specific-pathogen-free pigs by a genotype 4 strain of human hepatitis E virus. J. Med. Virol. 2008, 80, 1379-1386. [CrossRef] [PubMed]

81. Meng, X.J.; Halbur, P.G.; Haynes, J.S.; Tsareva, T.S.; Bruna, J.D.; Royer, R.L.; Purcell, R.H.; Emerson, S.U. Experimental infection of pigs with the newly identified swine hepatitis E virus (swine HEV), but not with human strains of HEV. Arch. Virol. 1998, 143, 1405-1415. [CrossRef] [PubMed]

82. Lee, Y.H.; Ha, Y.; Ahn, K.K.; Chae, C. Localisation of swine hepatitis E virus in experimentally infected pigs. Vet. J. Lond. Engl. 1997 2009, 179, 417-421. [CrossRef] [PubMed]

83. Williams, T.P.; Kasorndorkbua, C.; Halbur, P.G.; Haqshenas, G.; Guenette, D.K.; Toth, T.E.; Meng, X.J. Evidence of extrahepatic sites of replication of the hepatitis E virus in a swine model. J. Clin. Microbiol. 2001, 39, 3040-3046. [CrossRef] [PubMed]

84. Cossaboom, C.M.; Córdoba, L.; Sanford, B.J.; Piñeyro, P.; Kenney, S.P.; Dryman, B.A.; Wang, Y.; Meng, X.-J. Cross-species infection of pigs with a novel rabbit, but not rat, strain of hepatitis E virus isolated in the United States. J. Gen. Virol. 2012, 93, 1687-1695. [CrossRef] [PubMed]

85. Schlosser, J.; Eiden, M.; Vina-Rodriguez, A.; Fast, C.; Dremsek, P.; Lange, E.; Ulrich, R.G.; Groschup, M.H. Natural and experimental hepatitis E virus genotype 3-infection in European wild boar is transmissible to domestic pigs. Vet. Res. 2014, 45, 121. [CrossRef] [PubMed]

86. Schlosser, J.; Vina-Rodriguez, A.; Fast, C.; Groschup, M.H.; Eiden, M. Chronically infected wild boar can transmit genotype 3 hepatitis E virus to domestic pigs. Vet. Microbiol. 2015, 180, 15-21. [CrossRef] [PubMed]

87. Marek, A.; Bilic, I.; Prokofieva, I.; Hess, M. Phylogenetic analysis of avian hepatitis E virus samples from European and Australian chicken flocks supports the existence of a different genus within the Hepeviridae comprising at least three different genotypes. Vet. Microbiol. 2010, 145, 54-61. [CrossRef] [PubMed]

88. Billam, P.; Huang, F.F.; Sun, Z.F.; Pierson, F.W.; Duncan, R.B.; Elvinger, F.; Guenette, D.K.; Toth, T.E.; Meng, X.J. Systematic pathogenesis and replication of avian hepatitis $E$ virus in specific-pathogen-free adult chickens. J. Virol. 2005, 79, 3429-3437. [CrossRef] [PubMed]

89. Billam, P.; Pierson, F.W.; Li, W.; LeRoith, T.; Duncan, R.B.; Meng, X.J. Development and validation of a negative-strand-specific reverse transcription-PCR assay for detection of a chicken strain of hepatitis $\mathrm{E}$ virus: Identification of nonliver replication sites. J. Clin. Microbiol. 2008, 46, 2630-2634. [CrossRef] [PubMed]

90. Sun, Z.F.; Larsen, C.T.; Huang, F.F.; Billam, P.; Pierson, F.W.; Toth, T.E.; Meng, X.J. Generation and infectivity titration of an infectious stock of avian hepatitis E virus (HEV) in chickens and cross-species infection of turkeys with avian HEV. J. Clin. Microbiol. 2004, 42, 2658-2662. [CrossRef] [PubMed] 
91. Huang, F.F.; Pierson, F.W.; Toth, T.E.; Meng, X.J. Construction and characterization of infectious cDNA clones of a chicken strain of hepatitis E virus (HEV), avian HEV. J. Gen. Virol. 2005, 86, 2585-2593. [CrossRef] [PubMed]

92. Kwon, H.M.; LeRoith, T.; Pudupakam, R.S.; Pierson, F.W.; Huang, Y.-W.; Dryman, B.A.; Meng, X.-J. Construction of an infectious cDNA clone of avian hepatitis E virus (avian HEV) recovered from a clinically healthy chicken in the United States and characterization of its pathogenicity in specific-pathogen-free chickens. Vet. Microbiol. 2011, 147, 310-319. [CrossRef] [PubMed]

93. Pudupakam, R.S.; Huang, Y.W.; Opriessnig, T.; Halbur, P.G.; Pierson, F.W.; Meng, X.J. Deletions of the hypervariable region (HVR) in open reading frame 1 of hepatitis E virus do not abolish virus infectivity: Evidence for attenuation of HVR deletion mutants in vivo. J. Virol. 2009, 83, 384-395. [CrossRef] [PubMed]

94. Pudupakam, R.S.; Kenney, S.P.; Córdoba, L.; Huang, Y.-W.; Dryman, B.A.; Leroith, T.; Pierson, F.W.; Meng, X.-J. Mutational analysis of the hypervariable region of hepatitis e virus reveals its involvement in the efficiency of viral RNA replication. J. Virol. 2011, 85, 10031-10040. [CrossRef] [PubMed]

95. Cheng, X.; Wang, S.; Dai, X.; Shi, C.; Wen, Y.; Zhu, M.; Zhan, S.; Meng, J. Rabbit as a novel animal model for hepatitis E virus infection and vaccine evaluation. PLOS ONE 2012, 7, e51616. [CrossRef] [PubMed]

96. Han, J.; Lei, Y.; Liu, L.; Liu, P.; Xia, J.; Zhang, Y.; Zeng, H.; Wang, L.; Wang, L.; Zhuang, H. SPF rabbits infected with rabbit hepatitis E virus isolate experimentally showing the chronicity of hepatitis. PLoS ONE 2014, 9, e99861. [CrossRef] [PubMed]

97. Ma, H.; Zheng, L.; Liu, Y.; Zhao, C.; Harrison, T.J.; Ma, Y.; Sun, S.; Zhang, J.; Wang, Y. Experimental infection of rabbits with rabbit and genotypes 1 and 4 hepatitis E viruses. PLoS ONE 2010, 5, e9160. [CrossRef] [PubMed]

98. Mao, J.; Zhao, Y.; She, R.; Cao, B.; Xiao, P.; Wu, Q.; Guo, Z.; Ma, L.; Soomro, M.H. Detection and localization of rabbit hepatitis e virus and antigen in systemic tissues from experimentally intraperitoneally infected rabbits. PLoS ONE 2014, 9, e88607. [CrossRef] [PubMed]

99. Xia, J.; Liu, L.; Wang, L.; Zhang, Y.; Zeng, H.; Liu, P.; Zou, Q.; Wang, L.; Zhuang, H. Experimental infection of pregnant rabbits with hepatitis E virus demonstrating high mortality and vertical transmission. J. Viral Hepat. 2015, 22, 850-857. [CrossRef] [PubMed]

100. Liu, L.; Wang, L.; Xia, J.; Zhang, Y.; Zeng, H.; Liu, P.; Zou, Q.; Wang, L.; Zhuang, H. Mix-breeding with HEV-infected swine induced inapparent HEV infection in SPF rabbits. J. Med. Virol. 2016, 88, 681-685. [CrossRef] [PubMed]

101. Li, T.-C.; Yoshizaki, S.; Ami, Y.; Suzaki, Y.; Yasuda, S.P.; Yoshimatsu, K.; Arikawa, J.; Takeda, N.; Wakita, T. Susceptibility of laboratory rats against genotypes 1, 3, 4, and rat hepatitis E viruses. Vet. Microbiol. 2013, 163, 54-61. [CrossRef] [PubMed]

102. Maneerat, Y.; Clayson, E.T.; Myint, K.S.; Young, G.D.; Innis, B.L. Experimental infection of the laboratory rat with the hepatitis E virus. J. Med. Virol. 1996, 48, 121-128. [CrossRef]

103. Purcell, R.H.; Engle, R.E.; Rood, M.P.; Kabrane-Lazizi, Y.; Nguyen, H.T.; Govindarajan, S.; St Claire, M.; Emerson, S.U. Hepatitis E virus in rats, Los Angeles, California, USA. Emerg. Infect. Dis. 2011, 17, 2216-2222. [CrossRef] [PubMed]

104. Li, T.-C.; Yang, T.; Yoshizaki, S.; Ami, Y.; Suzaki, Y.; Ishii, K.; Haga, K.; Nakamura, T.; Ochiai, S.; Takaji, W.; et al. Construction and characterization of an infectious cDNA clone of rat hepatitis E virus. J. Gen. Virol. 2015, 96, 1320-1327. [CrossRef] [PubMed]

105. Zhu, Y.; Yu, X.; Zhang, Y.; Ni, Y.; Si, F.; Yu, R.; Dong, S.; Huang, Y.; Li, Z. Infectivity of a genotype 4 hepatitis E virus cDNA clone by intrahepatic inoculation of laboratory rats. Vet. Microbiol. 2013, 166, 405-411. [CrossRef] [PubMed]

106. Si, F.; Shi, B.; Wang, X.; Zhu, Y.; Liu, X.; Yang, Q.; Li, Z. Construction of an infectious cDNA clone of a swine genotype $3 \mathrm{HEV}$ strain isolated in Shanghai, China. Intervirology 2014, 57, 74-82. [CrossRef] [PubMed]

107. Li, T.-C.; Yang, T.; Yoshizaki, S.; Ami, Y.; Suzaki, Y.; Ishii, K.; Kishida, N.; Shirakura, M.; Asanuma, H.; Takeda, N.; et al. Ferret hepatitis E virus infection induces acute hepatitis and persistent infection in ferrets. Vet. Microbiol. 2016, 183, 30-36. [CrossRef] [PubMed]

108. Li, W.; Sun, Q.; She, R.; Wang, D.; Duan, X.; Yin, J.; Ding, Y. Experimental infection of Mongolian gerbils by a genotype 4 strain of swine hepatitis E virus. J. Med. Virol. 2009, 81, 1591-1596. [CrossRef] [PubMed]

109. Yang, Y.; Shi, R.; She, R.; Soomro, M.H.; Mao, J.; Du, F.; Zhao, Y.; Liu, C. Effect of swine hepatitis E virus on the livers of experimentally infected Mongolian gerbils by swine hepatitis E virus. Virus Res. 2015, 208, 171-179. [CrossRef] [PubMed] 
110. Bouwknegt, M.; Rutjes, S.A.; Reusken, C.B.; Stockhofe-Zurwieden, N.; Frankena, K.; de Jong, M.C.M.; de Roda Husman, A.M.; van der Poel, W.H.M. The course of hepatitis E virus infection in pigs after contact-infection and intravenous inoculation. BMC Vet. Res. 2009, 5. [CrossRef] [PubMed]

111. Shi, R.; Soomro, M.H.; She, R.; Yang, Y.; Wang, T.; Wu, Q.; Li, H.; Hao, W. Evidence of hepatitis E virus breaking through the blood-brain barrier and replicating in the central nervous system. J. Viral Hepat. 2016. [CrossRef] [PubMed]

112. Hong, Y.; He, Z.-J.; Tao, W.; Fu, T.; Wang, Y.-K.; Chen, Y. Experimental infection of Z:ZCLA Mongolian gerbils with human hepatitis E virus. World J. Gastroenterol. 2015, 21, 862-867. [PubMed]

113. Li, T.-C.; Suzaki, Y.; Ami, Y.; Tsunemitsu, H.; Miyamura, T.; Takeda, N. Mice are not susceptible to hepatitis E virus infection. J. Vet. Med. Sci. 2008, 70, 1359-1362. [CrossRef] [PubMed]

114. Huang, F.; Zhang, W.; Gong, G.; Yuan, C.; Yan, Y.; Yang, S.; Cui, L.; Zhu, J.; Yang, Z.; Hua, X. Experimental infection of Balb/c nude mice with Hepatitis E virus. BMC Infect. Dis. 2009, 9, 93. [CrossRef] [PubMed]

115. Allweiss, L.; Gass, S.; Giersch, K.; Groth, A.; Kah, J.; Volz, T.; Rapp, G.; Schöbel, A.; Lohse, A.W.; Polywka, S.; et al. Human liver chimeric mice as a new model of chronic hepatitis $\mathrm{E}$ virus infection and preclinical drug evaluation. J. Hepatol. 2016, 64, 1033-1040. [CrossRef] [PubMed]

116. Sayed, I.M.; Verhoye, L.; Cocquerel, L.; Abravanel, F.; Foquet, L.; Montpellier, C.; Debing, Y.; Farhoudi, A.; Wychowski, C.; Dubuisson, J.; et al. Study of hepatitis E virus infection of genotype 1 and 3 in mice with humanised liver. Gut 2016. [CrossRef] [PubMed]

117. Van de Garde, M.D.B.; Pas, S.D.; van der Net, G.; de Man, R.A.; Osterhaus, A.D.M.E.; Haagmans, B.L.; Boonstra, A.; Vanwolleghem, T. Hepatitis E virus (HEV) genotype 3 infection of human liver chimeric mice as a model for chronic HEV infection. J. Virol. 2016, 90, 4394-4401. [CrossRef] [PubMed]

118. Córdoba, L.; Feagins, A.R.; Opriessnig, T.; Cossaboom, C.M.; Dryman, B.A.; Huang, Y.-W.; Meng, X.-J. Rescue of a genotype 4 human hepatitis E virus from cloned cDNA and characterization of intergenotypic chimeric viruses in cultured human liver cells and in pigs. J. Gen. Virol. 2012, 93, 2183-2194. [CrossRef] [PubMed]

119. Feagins, A.R.; Córdoba, L.; Sanford, B.J.; Dryman, B.A.; Huang, Y.-W.; LeRoith, T.; Emerson, S.U.; Meng, X.-J. Intergenotypic chimeric hepatitis E viruses (HEVs) with the genotype 4 human HEV capsid gene in the backbone of genotype 3 swine HEV are infectious in pigs. Virus Res. 2011, 156, 141-146. [CrossRef] [PubMed]

120. Chatterjee, S.N.; Devhare, P.B.; Pingle, S.Y.; Paingankar, M.S.; Arankalle, V.A.; Lole, K.S. HEV-1 harbouring HEV-4 nonstructural protein (ORF1) replicates in transfected porcine kidney cells. J. Gen. Virol. 2016, 97, 1829-1840. [CrossRef] [PubMed]

121. Lara, J.; Purdy, M.A.; Khudyakov, Y.E. Genetic host specificity of hepatitis E virus. Infect. Genet. Evol. 2014, 24, 127-139. [CrossRef] [PubMed]

122. Bouquet, J.; Cheval, J.; Rogée, S.; Pavio, N.; Eloit, M. Identical consensus sequence and conserved genomic polymorphism of hepatitis E virus during controlled interspecies transmission. J. Virol. 2012, 86, 6238-6245. [CrossRef] [PubMed]

123. Tei, S.; Kitajima, N.; Takahashi, K.; Mishiro, S. Zoonotic transmission of hepatitis E virus from deer to human beings. Lancet 2003, 362, 371-373. [CrossRef]

124. Li, T.-C.; Chijiwa, K.; Sera, N.; Ishibashi, T.; Etoh, Y.; Shinohara, Y.; Kurata, Y.; Ishida, M.; Sakamoto, S.; Takeda, N.; Miyamura, T. Hepatitis E virus transmission from wild boar meat. Emerg. Infect. Dis. 2005, 11, 1958-1960. [CrossRef] [PubMed]

125. Riveiro-Barciela, M.; Mínguez, B.; Gironés, R.; Rodriguez-Frías, F.; Quer, J.; Buti, M. Phylogenetic demonstration of hepatitis E infection transmitted by pork meat ingestion. J. Clin. Gastroenterol. 2015, 49, 165-168. [CrossRef] [PubMed]

126. Renou, C.; Roque-Alfonso, A.; Pavio, N. Foodborne transmission of HEV from raw pork liver sausage in France. Emerg. Infect. Dis. 2014, in press. [CrossRef] [PubMed]

127. Yazaki, Y.; Mizuo, H.; Takahashi, M.; Nishizawa, T.; Sasaki, N.; Gotanda, Y.; Okamoto, H. Sporadic acute or fulminant hepatitis E in Hokkaido, Japan, may be food-borne, as suggested by the presence of hepatitis $\mathrm{E}$ virus in pig liver as food. J. Gen. Virol. 2003, 84, 2351-2357. [CrossRef] [PubMed]

128. Matsuda, H.; Okada, K.; Takahashi, K.; Mishiro, S. Severe hepatitis E virus infection after ingestion of uncooked liver from a wild boar. J. Infect. Dis. 2003, 188, 944. [CrossRef] [PubMed] 
129. Colson, P.; Borentain, P.; Queyriaux, B.; Kaba, M.; Moal, V.; Gallian, P.; Heyries, L.; Raoult, D.; Gerolami, R. Pig liver sausage as a source of hepatitis E virus transmission to humans. J. Infect. Dis. 2010, 202, 825-834. [CrossRef] [PubMed]

130. Yapa, C.M.; Furlong, C.; Rosewell, A.; Ward, K.A.; Adamson, S.; Shadbolt, C.; Kok, J.; Tracy, S.L.; Bowden, S.; Smedley, E.J.; et al. First reported outbreak of locally acquired hepatitis E virus infection in Australia. Med. J. Aust. 2016, 204, 274. [CrossRef] [PubMed]

131. Masuda, J.-I.; Yano, K.; Tamada, Y.; Takii, Y.; Ito, M.; Omagari, K.; Kohno, S. Acute hepatitis E of a man who consumed wild boar meat prior to the onset of illness in Nagasaki, Japan. Hepatol. Res. 2005, 31, 178-183. [CrossRef] [PubMed]

132. Tamada, Y.; Yano, K.; Yatsuhashi, H.; Inoue, O.; Mawatari, F.; Ishibashi, H. Consumption of wild boar linked to cases of hepatitis E. J. Hepatol. 2004, 40, 869-870. [CrossRef] [PubMed]

133. Guillois, Y.; Abravanel, F.; Miura, T.; Pavio, N.; Vaillant, V.; Lhomme, S.; Le Guyader, F.S.; Rose, N.; Le Saux, J.-C.; King, L.A.; et al. High proportion of asymptomatic infections in an outbreak of hepatitis $\mathrm{E}$ associated with a spit-roasted piglet, France, 2013. Clin. Infect. Dis. 2016, 62, 351-357. [CrossRef] [PubMed]

134. Wichmann, O.; Schimanski, S.; Koch, J.; Kohler, M.; Rothe, C.; Plentz, A.; Jilg, W.; Stark, K. Phylogenetic and case-control study on hepatitis E virus infection in Germany. J. Infect. Dis. 2008, 198, 1732-1741. [CrossRef] [PubMed]

135. Mansuy, J.M.; Gallian, P.; Dimeglio, C.; Saune, K.; Arnaud, C.; Pelletier, B.; Morel, P.; Legrand, D.; Tiberghien, P.; Izopet, J. A nationwide survey of hepatitis E viral infection in French blood donors. Hepatology 2016, 63, 1145-1154. [CrossRef] [PubMed]

136. Cossaboom, C.M.; Heffron, C.L.; Cao, D.; Yugo, D.M.; Houk-Miles, A.E.; Lindsay, D.S.; Zajac, A.M.; Bertke, A.S.; Elvinger, F.; Meng, X.-J. Risk factors and sources of foodborne hepatitis E virus infection in the United States. J. Med. Virol. 2016, 88, 1641-1645. [CrossRef] [PubMed]

137. Chaussade, H.; Rigaud, E.; Allix, A.; Carpentier, A.; Touzé, A.; Delzescaux, D.; Choutet, P.; Garcia-Bonnet, N.; Coursaget, P. Hepatitis E virus seroprevalence and risk factors for individuals in working contact with animals. J. Clin. Virol. 2013, 58, 504-508. [CrossRef] [PubMed]

138. Said, B.; Ijaz, S.; Chand, M.A.; Kafatos, G.; Tedder, R.; Morgan, D. Hepatitis E virus in England and Wales: Indigenous infection is associated with the consumption of processed pork products. Epidemiol. Infect. 2014, 142, 1467-1475. [CrossRef] [PubMed]

139. Pavio, N.; Merbah, T.; Thébault, A. Frequent hepatitis E virus contamination in food containing raw pork liver, France. Emerg. Infect. Dis. 2014, 20, 1925-1927. [CrossRef] [PubMed]

140. Di Bartolo, I.; Diez-Valcarce, M.; Vasickova, P.; Kralik, P.; Hernandez, M.; Angeloni, G.; Ostanello, F.; Bouwknegt, M.; Rodríguez-Lázaro, D.; Pavlik, I.; et al. Hepatitis E virus in pork production chain in Czech Republic, Italy, and Spain, 2010. Emerg. Infect. Dis. 2012, 18, 1282-1289. [CrossRef] [PubMed]

141. Di Bartolo, I.; Angeloni, G.; Ponterio, E.; Ostanello, F.; Ruggeri, F.M. Detection of hepatitis E virus in pork liver sausages. Int. J. Food Microbiol. 2015, 193, 29-33. [CrossRef] [PubMed]

142. Szabo, K.; Trojnar, E.; Anheyer-Behmenburg, H.; Binder, A.; Schotte, U.; Ellerbroek, L.; Klein, G.; Johne, R. Detection of hepatitis E virus RNA in raw sausages and liver sausages from retail in Germany using an optimized method. Int. J. Food Microbiol. 2015, 215, 149-156. [CrossRef] [PubMed]

143. Grierson, S.; Heaney, J.; Cheney, T.; Morgan, D.; Wyllie, S.; Powell, L.; Smith, D.; Ijaz, S.; Steinbach, F.; Choudhury, B.; et al. Prevalence of Hepatitis E Virus Infection in Pigs at the Time of Slaughter, United Kingdom, 2013. Emerg. Infect. Dis. 2015, 21, 1396-1401. [CrossRef] [PubMed]

144. Rose, N.; Lunazzi, A.; Dorenlor, V.; Merbah, T.; Eono, F.; Eloit, M.; Madec, F.; Pavio, N. High prevalence of Hepatitis E virus in French domestic pigs. Comp. Immunol. Microbiol. Infect. Dis. 2011, 34, 419-427. [CrossRef] [PubMed]

145. Bouwknegt, M.; Engel, B.; Herremans, M.M.P.T.; Widdowson, M.A.; Worm, H.C.; Koopmans, M.P.G.; Frankena, K.; de Roda Husman, A.M.; De Jong, M.C.M.; Van Der Poel, W.H.M. Bayesian estimation of hepatitis E virus seroprevalence for populations with different exposure levels to swine in The Netherlands. Epidemiol. Infect. 2008, 136, 567-576. [CrossRef] [PubMed]

146. Berto, A.; Martelli, F.; Grierson, S.; Banks, M. Hepatitis E virus in pork food chain, United Kingdom, 2009-2010. Emerg. Infect. Dis. 2012, 18, 1358-1360. [CrossRef] [PubMed]

147. Okano, H.; Takahashi, M.; Isono, Y.; Tanaka, H.; Nakano, T.; Oya, Y.; Sugimoto, K.; Ito, K.; Ohmori, S.; Maegawa, T.; et al. Characterization of sporadic acute hepatitis $\mathrm{E}$ and comparison of hepatitis $\mathrm{E}$ virus 
genomes in acute hepatitis patients and pig liver sold as food in Mie, Japan. Hepatol. Res. 2014, 44, E63-E76. [CrossRef] [PubMed]

148. Feagins, A.R.; Opriessnig, T.; Guenette, D.K.; Halbur, P.G.; Meng, X.-J. Detection and characterization of infectious Hepatitis E virus from commercial pig livers sold in local grocery stores in the USA. J. Gen. Virol. 2007, 88, 912-917. [CrossRef] [PubMed]

149. Lhomme, S.; Top, S.; Bertagnoli, S.; Dubois, M.; Guerin, J.-L.; Izopet, J. Wildlife reservoir for hepatitis E virus, southwestern France. Emerg. Infect. Dis. 2015, 21, 1224-1226. [CrossRef] [PubMed]

150. Serracca, L.; Battistini, R.; Rossini, I.; Mignone, W.; Peletto, S.; Boin, C.; Pistone, G.; Ercolini, R.; Ercolini, C. Molecular investigation on the presence of hepatitis $\mathrm{E}$ virus (HEV) in wild game in north-western Italy. Food Environ. Virol. 2015, 7, 206-212. [CrossRef] [PubMed]

151. Heldt, F.H.; Staggmeier, R.; Gularte, J.S.; Demoliner, M.; Henzel, A.; Spilki, F.R. Hepatitis E virus in surface water, sediments, and pork products marketed in southern Brazil. Food Environ. Virol. 2016, 8, $200-205$. [CrossRef] [PubMed]

152. Berto, A.; Grierson, S.; Hakze-van der Honing, R.; Martelli, F.; Johne, R.; Reetz, J.; Ulrich, R.G.; Pavio, N.; Van der Poel, W.H.M.; Banks, M. Hepatitis E virus in pork liver sausage, France. Emerg. Infect. Dis. 2013, 19, 264-266. [CrossRef] [PubMed]

153. Takahashi, H.; Tanaka, T.; Jirintai, S.; Nagashima, S.; Takahashi, M.; Nishizawa, T.; Mizuo, H.; Yazaki, Y.; Okamoto, H. A549 and PLC/PRF/5 cells can support the efficient propagation of swine and wild boar hepatitis E virus (HEV) strains: Demonstration of HEV infectivity of porcine liver sold as food. Arch. Virol. 2012, 157, 235-246. [CrossRef] [PubMed]

154. Mesquita, J.R.; Oliveira, D.; Rivadulla, E.; Abreu-Silva, J.; Varela, M.F.; Romalde, J.L.; Nascimento, M.S.J. Hepatitis E virus genotype 3 in mussels (Mytilus galloprovinciallis), Spain. Food Microbiol. 2016, 58, 13-15. [CrossRef] [PubMed]

155. Crossan, C.; Baker, P.J.; Craft, J.; Takeuchi, Y.; Dalton, H.R.; Scobie, L. Hepatitis E virus genotype 3 in shellfish, United Kingdom. Emerg. Infect. Dis. 2012, 18, 2085-2087. [CrossRef] [PubMed]

156. Song, Y.-J.; Jeong, H.-J.; Kim, Y.-J.; Lee, S.-W.; Lee, J.-B.; Park, S.-Y.; Song, C.-S.; Park, H.-M.; Choi, I.-S. Analysis of complete genome sequences of swine hepatitis $\mathrm{E}$ virus and possible risk factors for transmission of HEV to humans in Korea. J. Med. Virol. 2010, 82, 583-591. [CrossRef] [PubMed]

157. Li, T.-C.; Miyamura, T.; Takeda, N. Detection of hepatitis E virus RNA from the bivalve Yamato-Shijimi (Corbicula japonica) in Japan. Am. J. Trop. Med. Hyg. 2007, 76, 170-172. [PubMed]

158. Gao, S.; Li, D.; Zha, E.; Zhou, T.; Wang, S.; Yue, X. Surveillance of hepatitis E virus contamination in shellfish in China. Int. J. Environ. Res. Public. Health 2015, 12, 2026-2036. [CrossRef] [PubMed]

159. Grodzki, M.; Schaeffer, J.; Piquet, J.-C.; Le Saux, J.-C.; Chevé, J.; Ollivier, J.; Le Pendu, J.; Le Guyader, F.S. Bioaccumulation efficiency, tissue distribution, and environmental occurrence of hepatitis $\mathrm{E}$ virus in bivalve shellfish from France. Appl. Environ. Microbiol. 2014, 80, 4269-4276. [CrossRef] [PubMed]

160. Koizumi, Y.; Isoda, N.; Sato, Y.; Iwaki, T.; Ono, K.; Ido, K.; Sugano, K.; Takahashi, M.; Nishizawa, T.; Okamoto, H. Infection of a Japanese patient by genotype 4 hepatitis e virus while traveling in Vietnam. J. Clin. Microbiol. 2004, 42, 3883-3885. [CrossRef] [PubMed]

161. Said, B.; Ijaz, S.; Kafatos, G.; Booth, L.; Thomas, H.L.; Walsh, A.; Ramsay, M.; Morgan, D.; Hepatitis E Incident Investigation Team. Hepatitis E outbreak on cruise ship. Emerg. Infect. Dis. 2009, 15, 1738-1744. [CrossRef] [PubMed]

162. Brassard, J.; Gagné, M.-J.; Généreux, M.; Côté, C. Detection of human food-borne and zoonotic viruses on irrigated, field-grown strawberries. Appl. Environ. Microbiol. 2012, 78, 3763-3766. [CrossRef] [PubMed]

163. Maunula, L.; Kaupke, A.; Vasickova, P.; Söderberg, K.; Kozyra, I.; Lazic, S.; van der Poel, W.H.M.; Bouwknegt, M.; Rutjes, S.; Willems, K.A.; et al. Tracing enteric viruses in the European berry fruit supply chain. Int. J. Food Microbiol. 2013, 167, 177-185. [CrossRef] [PubMed]

164. Kokkinos, P.; Kozyra, I.; Lazic, S.; Bouwknegt, M.; Rutjes, S.; Willems, K.; Moloney, R.; de Roda Husman, A.M.; Kaupke, A.; Legaki, E.; et al. Harmonised investigation of the occurrence of human enteric viruses in the leafy green vegetable supply chain in three European countries. Food Environ. Virol. 2012, 4, 179-191. [CrossRef] [PubMed]

165. Loisy-Hamon, F.; Leturnier, G. Autochthonous cases of hepatitis E: Where does the virus come from? Impact of pig slurry treatment on reduction of the viral load and prevalence of the virus in food substrates. EuroReference 2015, 13, 13-18. 
166. McCreary, C.; Martelli, F.; Grierson, S.; Ostanello, F.; Nevel, A.; Banks, M. Excretion of hepatitis E virus by pigs of different ages and its presence in slurry stores in the United Kingdom. Vet. Rec. 2008, 163, 261-265. [CrossRef] [PubMed]

167. Pina, S.; Buti, M.; Cotrina, M.; Piella, J.; Girones, R. HEV identified in serum from humans with acute hepatitis and in sewage of animal origin in Spain. J. Hepatol. 2000, 33, 826-833. [CrossRef]

168. Fernández-Barredo, S.; Galiana, C.; García, A.; Vega, S.; Gómez, M.T.; Pérez-Gracia, M.T. Detection of hepatitis $\mathrm{E}$ virus shedding in feces of pigs at different stages of production using reverse transcription-polymerase chain reaction. J. Vet. Diagn. Investig. 2006, 18, 462-465. [CrossRef]

169. Kasorndorkbua, C.; Opriessnig, T.; Huang, F.F.; Guenette, D.K.; Thomas, P.J.; Meng, X.-J.; Halbur, P.G. Infectious swine hepatitis $\mathrm{E}$ virus is present in pig manure storage facilities on United States farms, but evidence of water contamination is lacking. Appl. Environ. Microbiol. 2005, 71, 7831-7837. [CrossRef] [PubMed]

170. Steyer, A.; Naglič, T.; Močilnik, T.; Poljšak-Prijatelj, M.; Poljak, M. Hepatitis E virus in domestic pigs and surface waters in Slovenia: Prevalence and molecular characterization of a novel genotype 3 lineage. Infect. Genet. Evol. 2011, 11, 1732-1737. [CrossRef] [PubMed]

171. Gentry-Shields, J.; Myers, K.; Pisanic, N.; Heaney, C.; Stewart, J. Hepatitis E virus and coliphages in waters proximal to swine concentrated animal feeding operations. Sci. Total Environ. 2015, 505, 487-493. [CrossRef] [PubMed]

172. Rutjes, S.A.; Lodder, W.J.; Lodder-Verschoor, F.; van den Berg, H.H.J.L.; Vennema, H.; Duizer, E.; Koopmans, M.; de Roda Husman, A.M. Sources of hepatitis E virus genotype 3 in The Netherlands. Emerg. Infect. Dis. 2009, 15, 381-387. [CrossRef] [PubMed]

173. Ishida, S.; Yoshizumi, S.; Ikeda, T.; Miyoshi, M.; Goto, A.; Matsubayashi, K.; Ikeda, H. Detection and molecular characterization of hepatitis $\mathrm{E}$ virus in clinical, environmental and putative animal sources. Arch. Virol. 2012, 157, 2363-2368. [CrossRef] [PubMed]

174. Iaconelli, M.; Purpari, G.; Della Libera, S.D.; Petricca, S.; Guercio, A.; Ciccaglione, A.R.; Bruni, R.; Taffon, S.; Equestre, M.; Fratini, M.; et al. Hepatitis A and E Viruses in Wastewaters, in River Waters, and in Bivalve Molluscs in Italy. Food Environ. Virol. 2015, 7, 316-324. [CrossRef] [PubMed]

175. Zhu, F.-C.; Zhang, J.; Zhang, X.-F.; Zhou, C.; Wang, Z.-Z.; Huang, S.-J.; Wang, H.; Yang, C.-L.; Jiang, H.-M.; Cai, J.-P.; et al. Efficacy and safety of a recombinant hepatitis E vaccine in healthy adults: A large-scale, randomised, double-blind placebo-controlled, phase 3 trial. Lancet 2010, 376, 895-902. [CrossRef]

176. Johne, R.; Trojnar, E.; Filter, M.; Hofmann, J. Thermal stability of hepatitis E virus estimated by a cell culture method. Appl. Environ. Microbiol. 2016. [CrossRef] [PubMed]

177. Emerson, S.U.; Arankalle, V.A.; Purcell, R.H. Thermal stability of hepatitis E virus. J. Infect. Dis. 2005, 192, 930-933. [CrossRef] [PubMed]

178. Feagins, A.R.; Opriessnig, T.; Guenette, D.K.; Halbur, P.G.; Meng, X.J. Inactivation of infectious hepatitis E virus present in commercial pig livers sold in local grocery stores in the United States. Int. J. Food Microbiol. 2008, 123, 32-37. [CrossRef] [PubMed]

179. Barnaud, E.; Rogée, S.; Garry, P.; Rose, N.; Pavio, N. Thermal inactivation of infectious hepatitis E virus in experimentally contaminated food. Appl. Environ. Microbiol. 2012, 78, 5153-5159. [CrossRef] [PubMed]

180. Withers, M.R.; Correa, M.T.; Morrow, M.; Stebbins, M.E.; Seriwatana, J.; Webster, W.D.; Boak, M.B.; Vaughn, D.W. Antibody levels to hepatitis E virus in North Carolina swine workers, non-swine workers, swine, and murids. Am. J. Trop. Med. Hyg. 2002, 66, 384-388. [PubMed]

181. Meng, X.J.; Wiseman, B.; Elvinger, F.; Guenette, D.K.; Toth, T.E.; Engle, R.E.; Emerson, S.U.; Purcell, R.H. Prevalence of antibodies to hepatitis E virus in veterinarians working with swine and in normal blood donors in the United States and other countries. J. Clin. Microbiol. 2002, 40, 117-122. [CrossRef] [PubMed]

182. Olsen, B.; Axelsson-Olsson, D.; Thelin, A.; Weiland, O. Unexpected high prevalence of IgG-antibodies to hepatitis E virus in Swedish pig farmers and controls. Scand. J. Infect. Dis. 2006, 38, 55-58. [CrossRef] [PubMed]

183. Drobeniuc, J.; Favorov, M.O.; Shapiro, C.N.; Bell, B.P.; Mast, E.E.; Dadu, A.; Culver, D.; Iarovoi, P.; Robertson, B.H.; Margolis, H.S. Hepatitis E virus antibody prevalence among persons who work with swine. J. Infect. Dis. 2001, 184, 1594-1597. [CrossRef] [PubMed]

184. Traoré, K.A.; Ouoba, J.B.; Huot, N.; Rogée, S.; Dumarest, M.; Traoré, A.S.; Pavio, N.; Barro, N.; Roques, P. Hepatitis E virus exposure is increased in pork butchers from Burkina Faso. Am. J. Trop. Med. Hyg. 2015, 93, 1356-1359. [CrossRef] [PubMed] 
185. Carpentier, A.; Chaussade, H.; Rigaud, E.; Rodriguez, J.; Berthault, C.; Boué, F.; Tognon, M.; Touzé, A.; Garcia-Bonnet, N.; Choutet, P.; et al. High hepatitis E virus seroprevalence in forestry workers and in wild boars in France. J. Clin. Microbiol. 2012, 50, 2888-2893. [CrossRef] [PubMed]

186. Dremsek, P.; Wenzel, J.J.; Johne, R.; Ziller, M.; Hofmann, J.; Groschup, M.H.; Werdermann, S.; Mohn, U.; Dorn, S.; Motz, M.; et al. Seroprevalence study in forestry workers from eastern Germany using novel genotype 3- and rat hepatitis E virus-specific immunoglobulin G ELISAs. Med. Microbiol. Immunol. 2012, 201, 189-200. [CrossRef] [PubMed]

187. Schielke, A.; Ibrahim, V.; Czogiel, I.; Faber, M.; Schrader, C.; Dremsek, P.; Ulrich, R.G.; Johne, R. Hepatitis E virus antibody prevalence in hunters from a district in Central Germany, 2013: A cross-sectional study providing evidence for the benefit of protective gloves during disembowelling of wild boars. BMC Infect. Dis. 2015, 15, 440. [CrossRef] [PubMed]

188. Cui, W.; Sun, Y.; Xu, A.; Gao, R.; Gong, L.; Zhang, L.; Jiang, M. Hepatitis E seroprevalence and related risk factors among seafood processing workers: A cross-sectional survey in Shandong Province, China. Int. J. Infect. Dis. 2016, 49, 62-66. [CrossRef] [PubMed]

189. Renou, C.; Cadranel, J.-F.; Bourlière, M.; Halfon, P.; Ouzan, D.; Rifflet, H.; Carenco, P.; Harafa, A.; Bertrand, J.J.; Boutrouille, A.; et al. Possible Zoonotic Transmission of Hepatitis E from Pet Pig to Its Owner. Emerg. Infect. Dis. 2007, 13, 1094-1096. [CrossRef] [PubMed]

(C) 2016 by the authors; licensee MDPI, Basel, Switzerland. This article is an open access article distributed under the terms and conditions of the Creative Commons Attribution (CC-BY) license (http:/ / creativecommons.org/licenses/by/4.0/). 